\title{
THE CAPIBARIBE PARK PROJECT, RECIFE: \\ USING THE RIVER TO REINVENT THE CITY
}

\section{PROJETO PARQUE CAPIBARIBE, RECIFE: REINVENTANDO A CIDADE A PARTIR DO RIO}

\section{Fabiano Rocha Diniz (1)}

Assistant professor, Universidade Federal de Pernambuco (UFPE) Recife (PE), Brasil.

\section{Luiz Vieira Filho}

Assistant professor, UFPE - Recife (PE), Brazil.

\section{Roberto Montezuma (D)}

Assistant professor, UFPE Recife (PE), Brazil.

\section{Correspondence address:}

Fabiano Rocha Diniz - Centro de Artes e Comunicação, Departamento de Arquitetura e Urbanismo, Universidade Federal de Pernambuco - Avenida da Arquitetura, s/n - Campus Universitário - CEP 50740-550Recife (PE), Brazil -

E-mail: fabiano.diniz@ufpe.br

Received on: $12 / 03 / 2019$

Accepted on: 04/20/2020

\section{ABSTRACT}

Recife is an amphibious city whose urban development does not value its rivers. In the past, the city's main watercourse, the river Capibaribe, was understood to play a key role in structuring urban spaces and providing connectivity. Since then, this understanding has dwindled, and the resulting situation is a cause of great concern. Recife City has turned its back on the banks of its rivers and neglected both their capacity to smooth and shape urban space, and their potential to create a coherent image of the city. Recife is one of those cities in the world that are most vulnerable to climate change, ranking $16^{\text {th }}$ in the list of world hotspots. In order to confront these challenges and rethink the role of the river that runs in the heart of Recife, researchers, architects, engineers, and sociologists from Research and Innovation for Cities - Universidade Federal de Pernambuco (INCITI-UFPE) were invited by the Recife City Hall to draw up plans for a park stretching along the river's banks. Capibaribe Park Project attempts to answer one key question: How can we use the river to transform the city? The park project is based on a structural approach to landscape and is guided by the precepts of sustainability and regeneration of public spaces, in line with the emerging paradigm that combines a cross-disciplinary and cross-sector approach with water-sensitive design and social participation. The present article presents an overview of the main characteristics and development of this project, its theoretical and methodological underpinnings, its contribution to society, and the results achieved so far. It shows how, in addition to the planned park, the project also envisages the installation of a much more extensive system of parks, as a first stage towards the creation of park-city by the $500^{\text {th }}$ anniversary of the foundation of Recife, in 2037.

Keywords: sustainability; Recife city; River Capibaribe; urbanism and landscaping; water-sensitive urban design.

\section{RESUMO}

Cidade anfíbia, o Recife não valoriza seus rios em seu ordenamento territorial. Principal curso d'água da cidade, o Capibaribe chegou a receber atenção correspondente ao seu papel de articulador e estruturador dos espaços urbanos no passado. Desde então, esse interesse reflui, resultando em um quadro preocupante: o Recife deu as costas ao rio, desprezando tanto sua função de organização e amenização dos espaços urbanos, quanto seu potencial de dar coesão à imagem da cidade. Frente ao processo de mudanças climáticas, a cidade é uma das mais vulneráveis, ocupando o 16 o lugar na lista de pontos de acesso mundiais. Para enfrentar essas problemáticas e revalorizar o papel no rio que atravessa o coração da cidade, pesquisadores, arquitetos, engenheiros e sociólogos do Pesquisa e Inovação para as Cidades - Universidade Federal de Pernambuco (INCITI-UFPE) foram convidados pela Prefeitura da Cidade do Recife para projetar um 
parque linear às suas margens. O objetivo do Projeto Parque Capibaribe era responder à uma questão chave: como transformar a cidade a partir do rio? Fundado em uma abordagem estrutural da paisagem e guiado por preceitos como a sustentabilidade e a requalificação de espaços públicos, o projeto alinha-se com um paradigma em formação, associando aspectos como a integração setorial e disciplinar, a sensibilidade para com as águas e a participação social para efetivação do parque. Este artigo resume o desenvolvimento desse projeto, seus referenciais teórico-metodológicos e resultados, sua natureza e contribuições. Revela-se que, além do projeto de um parque, consolidou-se a perspectiva de estruturação de um sistema de parques, primeiro passo rumo à concepção de uma cidade parque no ano de 2037, ano em que o Recife festeja seus 500 anos.

Palavras-chave: sustentabilidade; Recife; Rio Capibaribe; urbanismo e paisagismo; urbanismo sensível às águas.

\section{INTRODUCTION}

Recife is well known as a city intimately related to the waterways that run in it. It is described as such in many poems and literature works. Some of these describe the city in a glowing light, full of civic pride. It is the city "where the rivers Capibaribe and Beberibe meet to form the Atlantic Ocean" (as the local saying goes), or the city that is "part imagination, part robbed from the sea" (CARNEIRO LEÃO, 1999, p. 129). At other times, it has been denigrated: viewed as a "dog without feathers" - an unattractive living being that has lost everything of its own (MELO NETO, 1999, p. 103-116) - the final setting of the peregrinations of the migrant worker Severino (MELO NETO, 1999, p. 103-116), burdened with his whole family by the cruel cycle of the "man who lives like a crab" (CASTRO, 1967, p. 13-14).

These citations picture Recife as an "amphibious city" (CASTRO, 1954, p. 23), a place where "anything that is not water, either has been or will be water" (OLIVEIRA, 1942, p. 48), in which "it is hard to know where the river begins... and where man, where his skin begins from the mud" (MELO NETO, 1999, p. 103-116). As an estuarine city subject to the vicissitudes of the tides and river currents, Recife was deemed suitable for the construction of a port in the $16^{\text {th }}$ century. At that time, it was a small coastal island sheltered by coral reefs, from which it got the name (from Arabic "ár-raçif", meaning dike, wharf, breakwater, DINIZ, 2010, p. 33), in 1537, of Reef Harbor Estuary.

The development of the city also owes a great deal to the navigable river Capibaribe, along which people and merchandise travelled between sugar mills and the port, connecting the floodplains, in the west, to the At- lantic Ocean, in the east. Throughout its history, Recife developed by way of a series of urban planning, architectural and landscaping interventions, which resulted in a city of stunning landscapes. From the very beginning, the sea, the estuary, the rivers, the streams, and canals have made their presence felt, providing open spaces and broad vistas of varying scales within the hydrographic basin that structures the locale. Recife's history of landscape architecture dates back to the $16^{\text {th }}$ century, with the creation of Count John Maurice of Nassau-Siegen's Freiburg Palace Park, by the architect Pieter Post (Figure 1), and the drawing up of an urban plan in which the waters of the canals and the winding river structured the morphology of the city center in the early stages of its development, in typically Dutch fashion. This tradition consolidated landmarks such as Avenida Martins de Barros, the area surrounding Praça da República and Rua da Aurora, and the State Governor's Palace, near the original site of Nassau's Palace (Figure 2).

Currently listed among the 16 cities in the world most vulnerable to the effects of climate change (IPCC, 2013), Recife no longer respects its rivers. The hydrographic basin of the river Capibaribe - the river of the capybaras, the most important watercourse in the city - is associated to the fragility of the fluvial and estuarine environment, its dynamics and its capacity to withstand the effects of extreme climate events. This underlines the extent to which the environment in which Recife is located is susceptible to these ill effects. Furthermore, factors relating to urban systems and infrastructure, modes of production and urban life, planning tools, projects and management may increase or 
lower the risk of accidents, underlining the vulnerability of this society and the lands it occupies.

Building resilience in such a society and physical environment, with this hydrological dynamic, requires urgent acknowledgement of the urban and landscape features of the river basin and of the way it has been appropriated and occupied by residents. Resilience is translated into the ability societies and urban structures of reacting to and recovering from accidents and disasters. Good practices in other countries (ROBERTS;
GORE; BULKELEY, 2018) show that there is no other way to introduce measures and practices that favor resilience in Recife, especially those related to the effects of extreme weather events, such as flooding and torrential rain.

A recent experience of the development of Capibaribe Park Project (INCITI-UFPE, 2019) testifies to the scale of the challenge posed. The initial aim of the project was to ascertain the physical-environmental and socio-spatial patterns of occupation of riverbank spaces

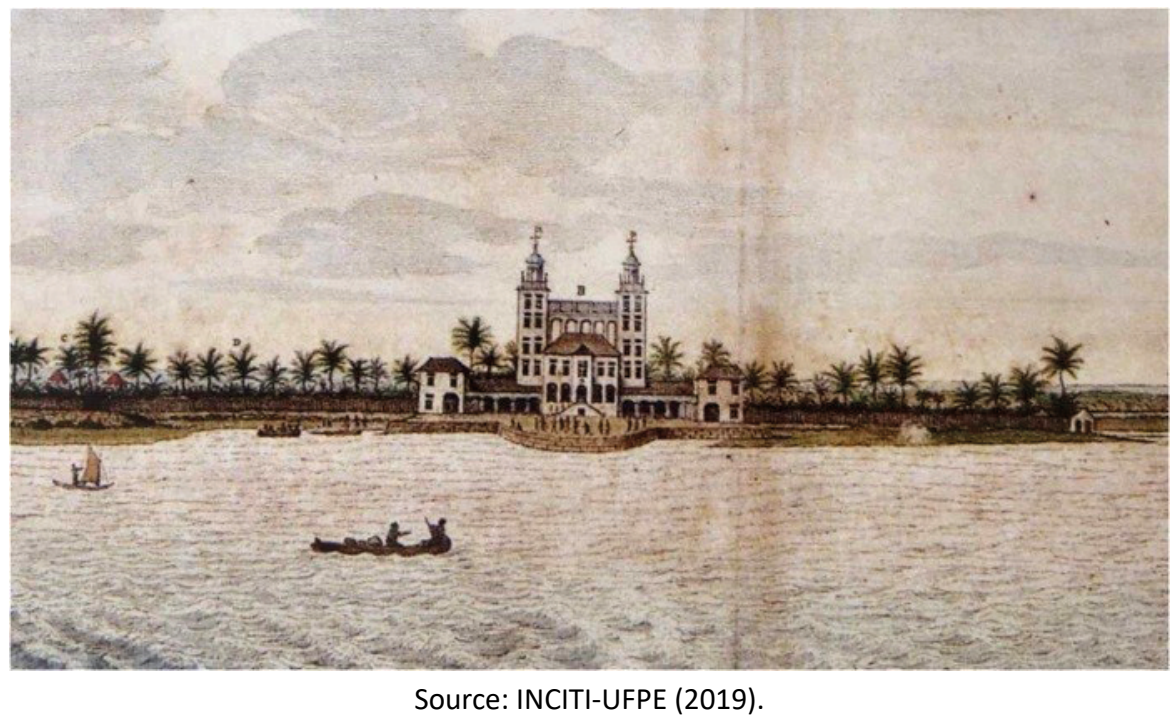

Figure 1 - Freiburg Palace (17 ${ }^{\text {th }}$ century).

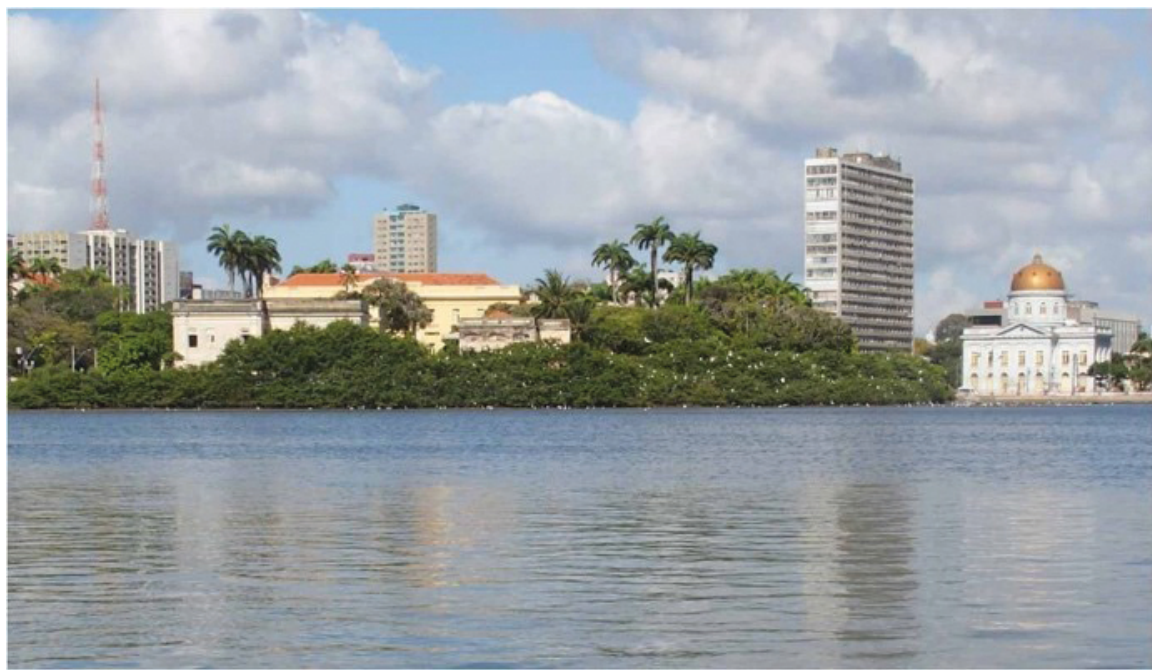

Source: INCITI-UFPE (2019)

Figure 2 - Campo das Princesas Palace (19 ${ }^{\text {th }}$ century). 
to transform them. The overall objective, from a managerial point of view (as a collaboration between municipal government and university), was to draw up intervention/action guidelines for changes based on the idea of a linear park along river banks. In terms of scientific research, the aim was to investigate the object of research in more depth, building up methodologies and new knowledge for the purpose of urban land use planning, guided primarily by the relation between water and the city, and the key question of how to use the river to transform the city.

Adapting to the complexity of the inter-related issues involved, the methodology adopted was based on urban ecology, which studies "the interactions between organisms, built structures and the natural environment, in which people congregate within the city" (FORMAN et al., 2014, p. 312). Thus, the physical features (the natural and built environment), and social and environmental dynamics (the economy, mobility, management, the biome, water resources, the climate, and so forth) are compared as a way of guiding development at an acceptable level of sustainability as to the ecosystem, economic and social balance.

With the aid of strategic planning tools, the project provides a vision of the future for Recife on its $500^{\text {th }}$ anniversary (in 2037), based on a refoundation of the city and its reintegration into the system of waterways from which it emerged. Social participation is the tool used to build up this set of guidelines, involving experts and ordinary citizens working together to use the river to reinvent the city. The focus of the studies, in terms of theme and geographical location, has shifted with the progression of research. At first, the initiative concentrated on the riverside itself, but the project has progressively broadened its scale and scope to cover a whole range of guidelines for the restructuring of the city on a larger scale, later including Beberibe and Tejipió river basins and the city as a whole.

During this experiment, another kind of technical change was envisaged, which subsequently became a specific objective. Interventions were formerly restricted to the physical control of water, conducted primarily by engineers, involving artificialization and pollution of watercourses. However, the increasing intensity and frequency of extreme weather events, such as floods, disasters and the resulting damage, led to the adoption of a new paradigm of sensitive design, regarding urban water resources as part of the overall ideal of sustainability. This has involved experts from fields other than Hydrology, including architects and urban planners.

Therefore, we describe herein the process underlying the development of Capibaribe Park Project, its content and the results achieved so far, and show how they are linked to the latest progressive principles that help hydrologists, urban planners and landscape architects to work together for conceiving and constructing sustainable cities of the future and improving the quality of our lives.

\section{THE MAIN ISSUE: RECIFE, LAND-USE PLANNING, AND MANAGEMENT OF URBAN WATER RESOURCES}

The river Capibaribe is an essential part of Recife's territory and identity, having guided its urban development over time. However, its potential to create a landscape that brings the city together is being neglected for decades. Urban sprawl, fueled by a focus on roadways between the 1950s and 1980s, and the absence of an overall city project distanced the city (built by humans) from its natural environment and citizens alike.

The road system ignores pedestrians and cyclists, squeezing them out onto narrow pavements and cycle paths, with inadequate tree covering, public spaces commandeered for parking, both air and noise pollution, and poor security. In this amphibious city, streams were turned into canals, straightened, clad in concrete, and confined between roads. The banks and beds of rivers were occupied by informal housing, impeding natural drainage, and destroying ecosystems associated to riverside vegetation. River banks were affected by unfettered urbanization and used for roads. One project aimed to install four-lane expressways along the full length of Capibaribe on either side. Riverside vegetation was destroyed or altered, and is now mostly composed of non-native species. Despite that, vegetation is still abundant and provides a habitat for a surprisingly diverse fauna, including capybaras, alligators and otters in the river and on its banks; and marmosets and various species of bird in the boughs of trees (Figure 3 ). 


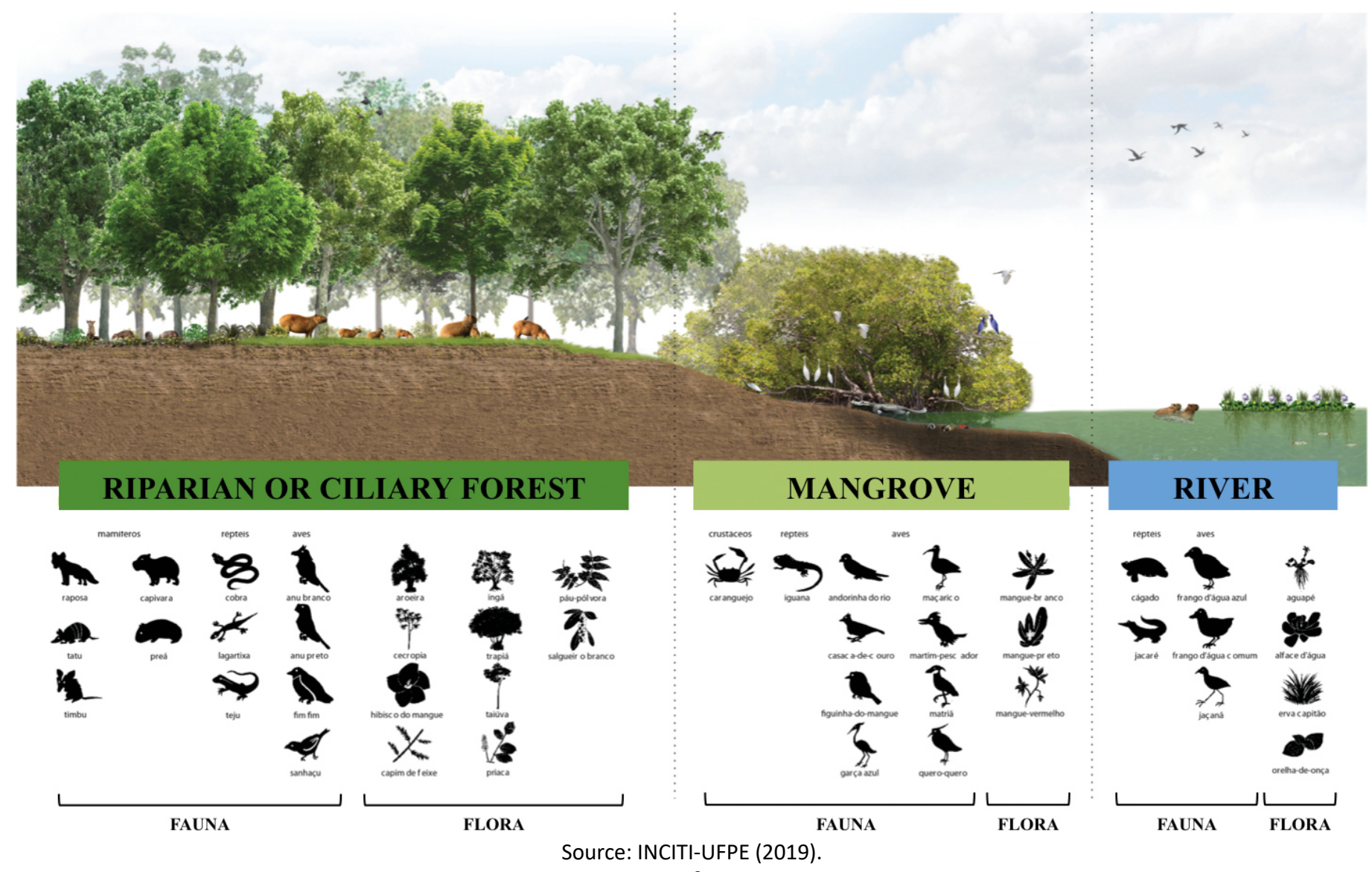

Figure 3 - Survey of Ecosystem Fauna.

Recife became a city where land is mostly occupied in an irregular or informal manner, with no planning, and flagrant disregard for urban planning laws, physical and environmental constraints, and the lay of the land. In 2014, the Municipal Sanitation Authority (Autarquia de Saneamento do Recife - SANEAR) calculated that over $33 \%$ of land in the city is occupied by low-income settlements, with $53 \%$ of the population living in such areas (RECIFE, 2016). According to the 2010 Census by the Brazilian Institute of Geography and Statistics (Instituto Brasileiro de Geografia e Estatística - IBGE), such individuals totaled over 825,000 (IBGE, 2010). The Atlas of Human Development of the RMR (PNUD; IPEA; FJP, 2014) shows that the poorest and most vulnerable people live in the most at-risk areas (Figure 4).

It is no coincidence that these areas are also places where the city conflicts with its waters, with flooding of low-lying areas, landslides, water shortages, and sewage pollution on all sides. However, the conflict be- tween the water dynamics and a pattern of land occupation that is not sensitive to this, with the attendant risks and impacts, is not restricted to underprivileged neighborhoods. Areas inhabited by higher income strata also follow the model of separation of residents, river, and nature. The automobile culture, that chokes the river and its streams, now all channeled into canals, constantly makes its presence felt.

In recent years, the relation between the city and nature has once again attracted the attention of scholars and urban managers. The constraints and opportunities presented by natural features for restructuration, organization and oversight of cities became an essential guide for urban planning. Bourdeau-Lepage (2016) spurs reflection on new approaches to urban planning, suggesting new parameters for work in this field. Resolution of the conflicts between the city and nature require that we abandon the ideal of mastering nature and, instead, seek to reveal its hidden face, 


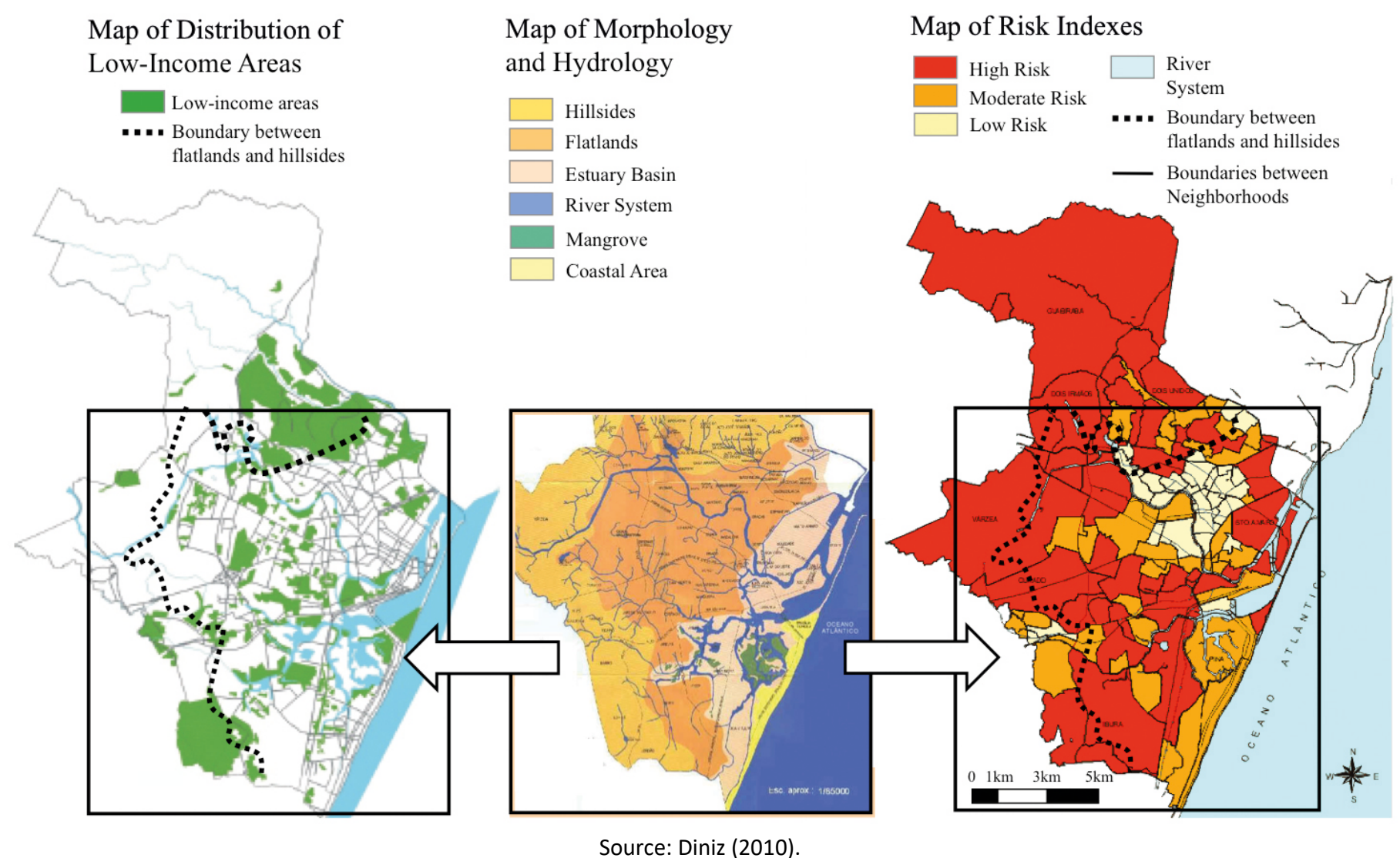

Figure 4 - Land use, relations between urban water resources, poverty, substandard housing, and at-risk areas.

insofar as this accords with the needs and desires of citizens.

Water management is related to land-use planning, both because water resources influence and determine the spatial configuration of human occupation, and because of the influence the latter have in turn on watercourses and flooding. On the one hand, water shapes space, with winding rivers that guide the course of roadways and other urban structures (thoroughfares, leisure areas, and open spaces, in particular). On the other hand, these aspects, in turn, shape the distinct patterns of land use, determining its density, according to the availability of drinkable water or restrictions on the occupation of land prone to flooding or landslides.

There is another kind of relationship between water/nature and city/artifact: the potential to generate or suppress the conditions essential for a good quality of urban life, like expounded by Lima and Garcez (2017). This may be objective, as in the supply of wa- ter in sufficient quantities and of sufficient quality for human settlements; or subjective, as in the case of the pleasure that aquatic landscapes furnish, as perceived and experienced by citizens. Either way, these relationships play a fundamental role in creating sustainability: the key notion of the emerging paradigm regarding urban waters.

Brodach and Goffi (2005) argue that sustainable development of cities depends on their capacity to create a balance between the urban system and the human and natural environments. In a rapidly changing urban environment, resilience requires physical elements (site conditions; unpredictable climate events) to be related to social ones (socioeconomic dynamics, at-risk populations, distribution of infrastructure and urban services, planning and management systems). Pincetl (2005) notes that improved quality of life of citizens is the ideal that guides the principles that determine the shape and density of urban environments. The growth of cities, their populations, 
and consumer's demands resulted in changes that affect "the health of ecosystems" which form part of the physical structure of cities (PINCETL, 2005, p. 209). We need good knowledge of a city to build and oversee it in such a way to gradually improve its formal and operational aspects, preserving the quality of life of its residents.

A sustainable city has a balanced ecosystem, whose structural features (the physical elements and relationships between them) respond to the level of evolution of functional needs (activities, flows, and decision-making), its crises and transformations. In the context of climate change, with more frequent accidents and disasters, a resilient city is one in which these elements combine in such a way as to allow it (in order of priority) to resist, react to and recover from the material and human impacts and the damage they cause.

Sustainable urban development requires sustainable management of city water resources that considers the need to focus on the specificities of the processes of land-use planning and their natural, physical, social and political determinants. Places where natural factors dictated by water resources and the action of social organizations occupying space overlap, we can adopt the view posited by Brun (2006), according to which urban water management requires a land-use planning approach. It should be seen in the context of policies regarding land use, coordinated at the sectoral level of zoning and urban planning.

In the clash between urbanization and water resource dynamics, the basic issues that lead to systemic disequilibrium stem from the complex process of producing the urban space. They involve the social and environmental factors that drive or restrain it, the specific interests and status of individuals and institutions involved in conducting the process, and the human experiences and relationships created by it. In other words, we need to address issues of susceptibility and vulnerability and build urban resilience based on coexistence with water resources. These are land-use issues susceptible to planning.

However, to achieve this, we need the effective involvement of various fields of knowledge associated with water resources and cities. In water management, there is a need for dialogue on two levels:

- between distinct sectors, involving cross-sector work on urban policies (environment, urban planning, landscaping, urban control, civil defense, urban cleaning, as well as water management);

\section{Inter-Sector Integration}

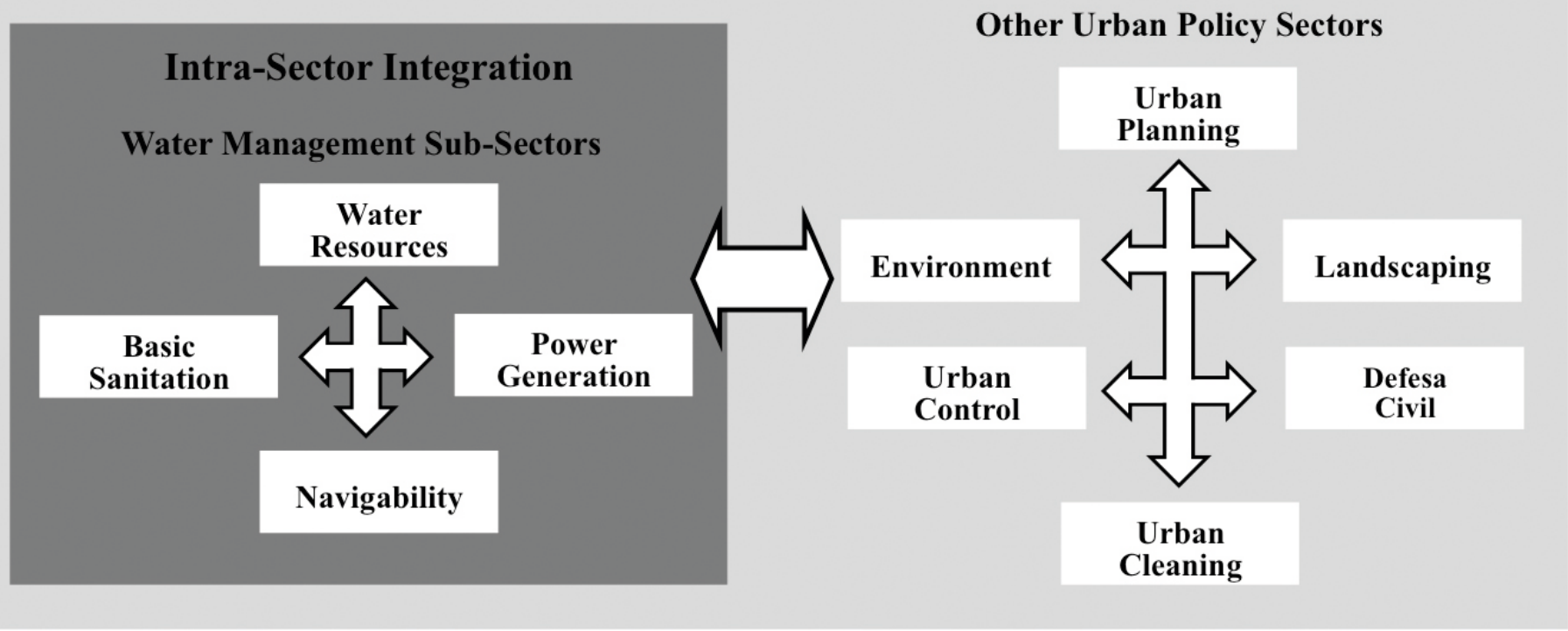

Source: Diniz (2010)

Figure 5 - Overview of Inter- and Intra-Sector Integration. 
- between water management sub-sectors (basic and environmental sanitation, water resources, power generation, navigability) (Figure 5).

This integrated approach to land-use planning is complex, but water is the cross-cutting issue. It contains the oft-neglected factor of the landscape as a key component of environmental, health and land-use planning policies. A multifaceted issue, which addresses human, social and natural sciences, landscape can either be viewed as a set of (physical, palpable) material and (cultural, subjective) immaterial elements, or as the result of the impact of human activities on the natural environment, filtered by the human eye when in contact with the landscape in everyday existence. Created by human activities in space (DOLLFUS, 1990), landscape only exists when it is perceived by all senses-smell, touch, hearing, sight-with the latter being essential for perceiving the physical spatial aspects of this landscape.

Despite the constraints on such integration, bringing together multidisciplinary fields and distinct public policy sectors opens a new range of possibilities. Urban land-use planning does not usually consider landscape issues to be important, because of a technical culture that pays little regard to the subtler aspects of relation- ships between society and the built spaces in which people live. Landscape architecture, as a project intervention that aims to order (natural and artificial spatial elements), aims to promote or facilitate sensitive human experiences of the environment, as a supplement to the improvement of urban habitats. In the case of Recife and its main river, this field of work is not only desirable but necessary.

In order to confront the challenges outlined above, there is a need for bold cultural change, broadening the range of fields and techniques available to planners and city managers, supported by the theoretical and methodological inputs that founded the project. A mixture of disciplines is one of the innovations presented for urban interventions that aim to fulfill the complex task of building sustainability and resilience, in a manner that balances the city's growth with conservation of ecosystems. The ecosystems created by rivers enhance the quality of urban habitats, enhancing our enjoyment of it and mitigating risks. Although Capibaribe Park Project does not aim to achieve the level of re-naturalization entertained by Brun, Coursière and Casetou (2014), its methodology, presented below, helps to create such a culture, and to aid understanding and practical application of it.

\section{METHODOLOGICAL AND EMPIRICAL CONSIDERATIONS: CAPIBARIBE PARK PROJECT AS AN EXERCISE IN RESOLVING CONFLICTS BETWEEN THE CITY AND ITS WATERS}

Seeking to change an already deep-rooted culture, old customs and practices that have often been traditionally accepted as the most appropriate must be broken. This is what researchers from Universidade Federal de Pernambuco and the members of the Research and Innovation for Cities Group (INCITI-UFPE) have done to some extent. In 2011 (in Amsterdam) and 2012 (in Recife), these professionals staged an international workshop, the Recife Exchange Amsterdam (RxA), as part of a partnership between UFPE and ARCAM (Amsterdam Center for Architecture), in which they developed the metaphor of Recife as a water tree (Figure 6), in which the water system structures land use.

The approach adopted considers a broad range of questions to shed light on the dynamics of watercourses and their effect on space in Recife City, as a result of the social and spatial practices that constitute that urban space. Elements of a physical and social nature, and subjective (sensible) and objective (measurable) features were studied, bearing in mind the distinct kinds of information on issues relating to natural and artificial environments. This task involved the mobilization and cooperation of professionals and researchers from a diversity of fields: architects, urbanists, engineers, historians, geographers, social scientists, communicators and designers. The water tree sums up this dynamic system and its components, the roots being the (predominantly conflictual) relationships between water and human beings in the urban environment.

The method used and the results achieved, albeit at a preliminary proposal stage, attracted the attention of the local authorities and, in 2013, INCITI-UFPE was in- 


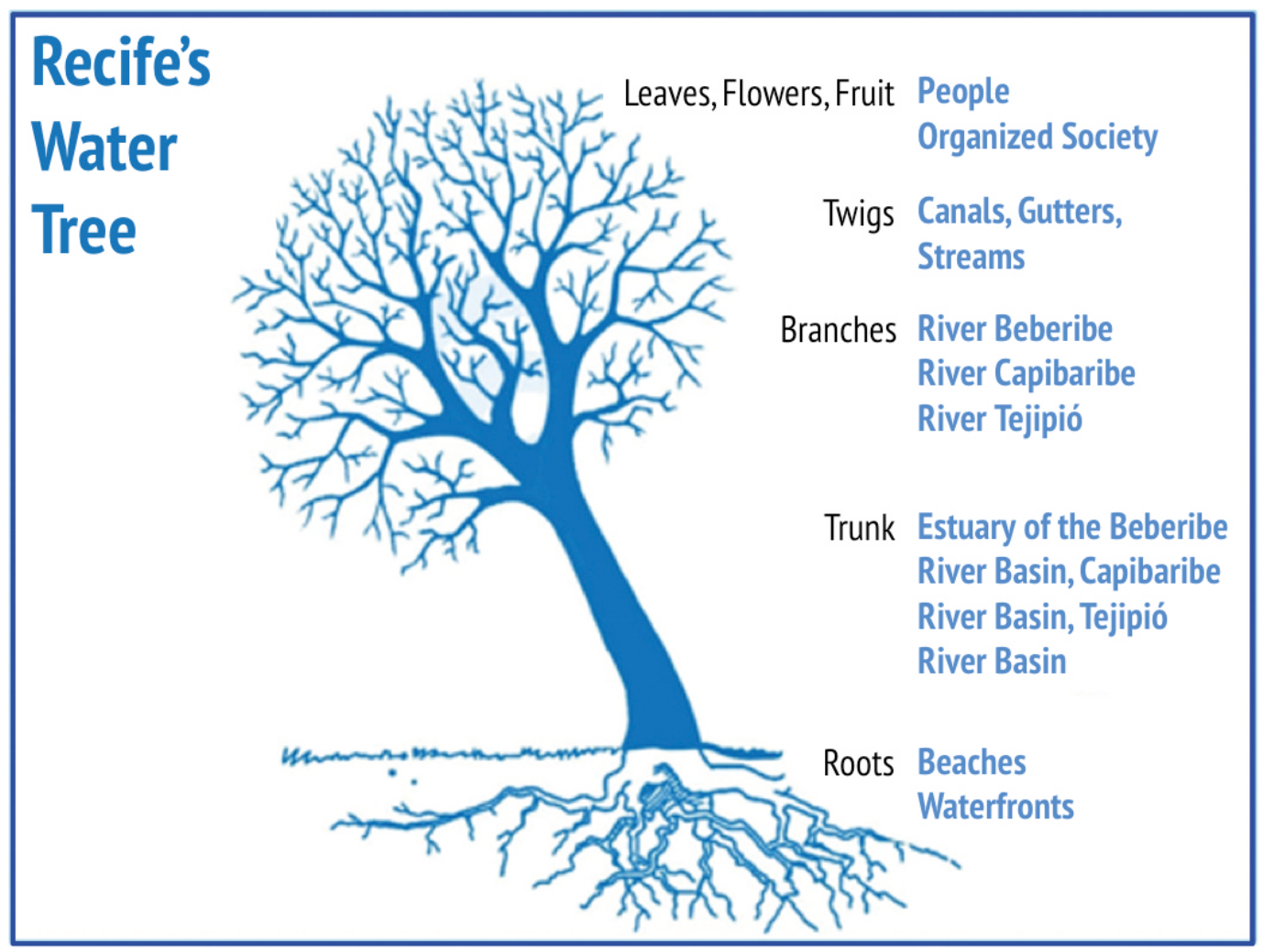

Source: INCITI-UFPE (2019).

Figure 6 - The Water Tree.

vited by Recife City Hall to support a return to a more positive relationship between the river and the people of Recife, promoting vitality and quality of urban life. This request was further developed into a partnership between INCITI-UFPE and the Municipal Department of the Environment and Sustainability (Secretaria de Meio Ambiente e Sustentabilidade de Pernambuco SEMAS-PCR) to develop the project for a park alongside the banks of the river Capibaribe. The project adopted an interdisciplinary approach, mobilizing 40 researchers and professionals divided up into 12 study groups in various higher education institutions. Individuals from various fields of expertise collaborated, and fieldwork was conducted on issues such as Sustainable development, Urban design, Mobility and Accessibility, Botany, Biology, Morphology, Ergonomics, Housing, Engineering, Landscape architecture, Sociology, Law, Economics, History, and Water resources. Eight empirical studies were carried out in collaboration with international teaching institutions, following the workshops, such as
Recife Exchange Holland (RXH), held in 2019 as a continuation of Brazilian-Dutch co-operation, now including French partners.

Since the early days of the PCR-UFPE partnership, studies of land-use planning have pointed to the urgent need to adopt a novel approach, expanding not only the geographical scope of project surveys and analyses, but also the dynamics associated to the promotion of quality of the spaces covered by the interventions. In the end, the work undertaken resulted in the proposal of an urban landscape intervention covering 42 neighborhoods and a surface area of 7,744 hectares, and affected the everyday life of roughly 445,000 citizens. A large amount of information regarding the fluvial and riverine environments was accumulated. The data gathered guided the macro-guidelines for land-use planning and a variety of actions that aim to use the river Capibaribe to transform the city. These guidelines start out from the premise that the river forms an axis that brings together various systems: the environment, 
non-motorized transportation, shared streets, canals, parks, and squares. This park's landscape, covering 30 $\mathrm{km}$ of river bank, whose fauna and flora form an ecological corridor, already exists. The challenge is to consolidate and expand it, with gradual regeneration and installation of new green areas and urban equipment, as the needs of riverside communities and the population of the city in general dictate.

Heedful of the concepts and principles of urban ecology, Capibaribe Park Project also adopted approaches from emerging urban planning theory, with citizen participation being a key plank in the development of proposals. Although actively promoted, this participation involves bottom-up management processes, thereby strengthening the spontaneous character of subsequent experiences and the practice of negotiation. The concept of tactile urbanism was also adopted, enabling citizens to participate both in the development of innovative ideas and solutions, and in the construction and experimental implementation of tangible physical models (prototypes) prior to full-scale installation. These conceptual and methodological benchmarks form the basis of the principles outlined by Capibaribe Project in its Urban Development and Environmental Recovery Plan (Plano Urbanístico de Recuperação Ambiental do Parque Capibaribe - PURA).

The guiding threads of the methodological schema presented in Figure 7 are interdisciplinarity, participation and experimentation. The studies and urban structures developed examine factors relating to the natural world, social forces, infrastructure, and services. To ensure that project implementation abides by the arrangement agreed by public authorities, society, and the university, the PURA and specific legislation

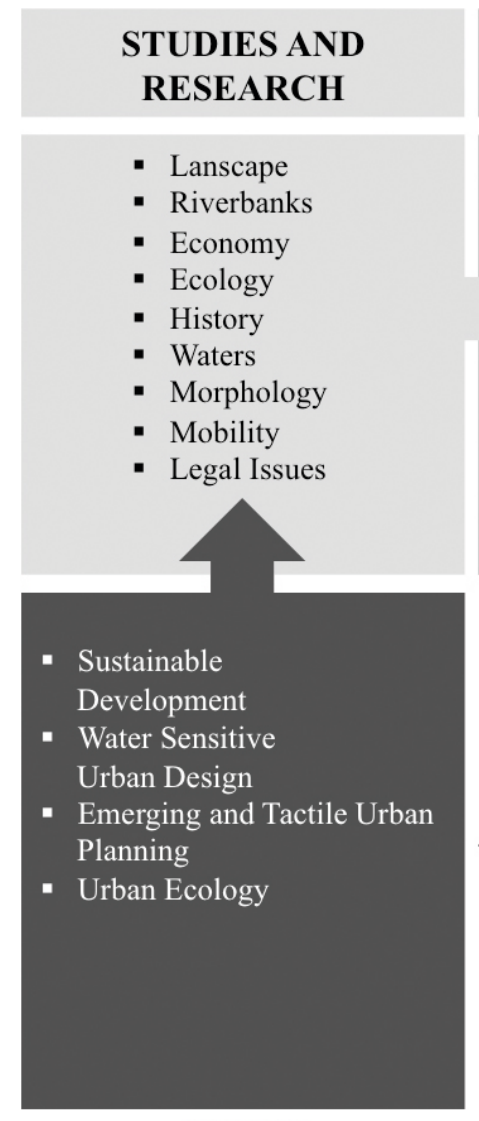

INPUTS

(Conceptual Guides)

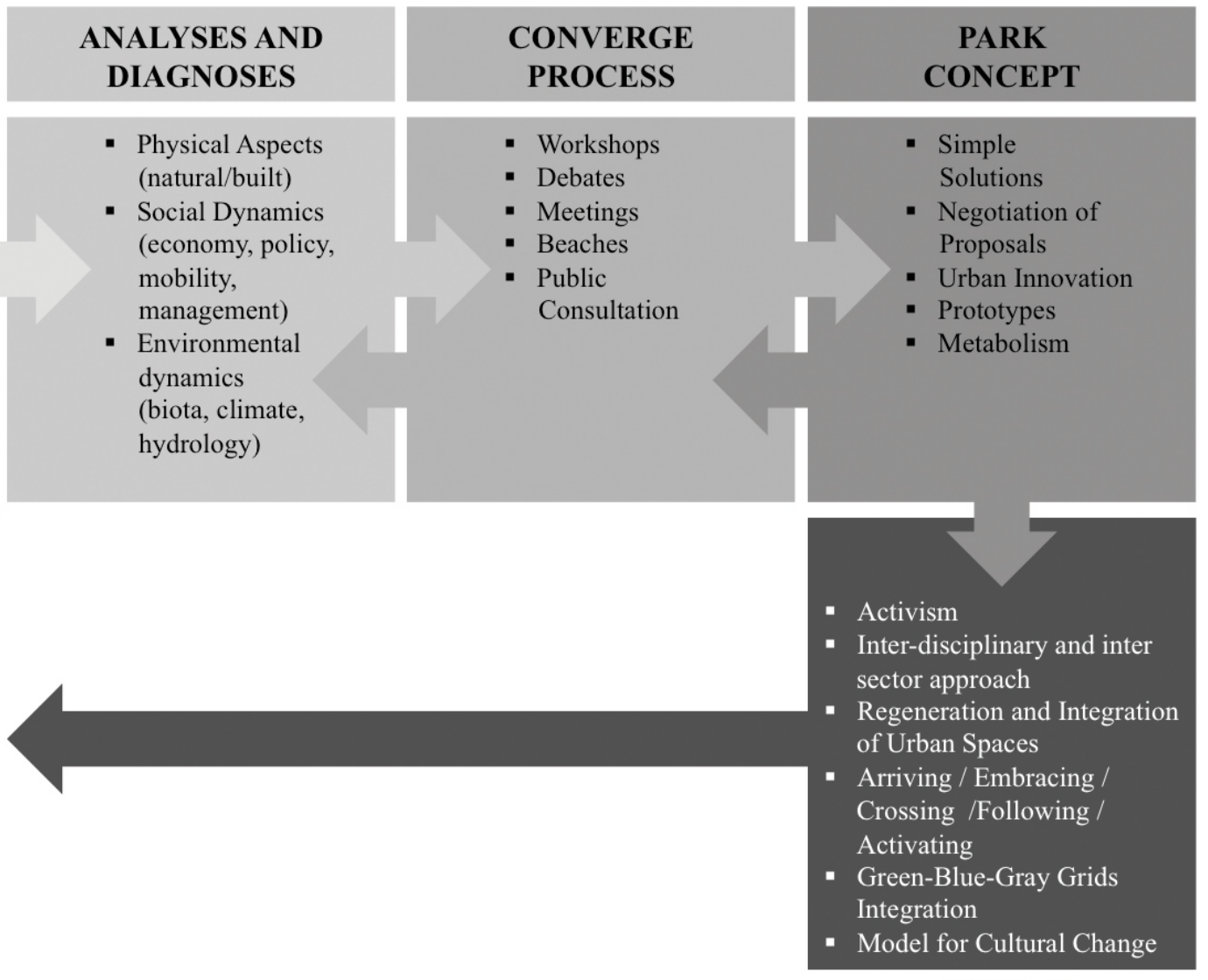

OUPUTS

(Guidelines, Premises)

Figure 7 - Capibaribe Park Project Methodology (schema). 
relating to the park established medium- to long-term urban intervention guidelines and assurances that the basic precepts of the project will be safeguarded despite changes of government at the local level.

With Capibaribe promoting social and spatial integration, and environmental recuperation and encouraging non-motorized transportation, the PURA consolidated its guiding principles:

- adopting simple solutions: promoting low-complexity, low-cost urban and environmental transformation with high potential for social transformation;

- negotiating proposals: mobilizing various stakeholders to develop joint action;

- promoting innovation in urban planning: developing and implementing urban planning solutions appropriate to the context of each setting, to the needs of each culture and to the requirements of future generations;

- building prototypes: developing solutions that can be implemented experimentally and evaluated, and promoting a feeling of belonging in relation to public places on the river banks;

- metabolizing: expanding the urban planning concerns proposed for the area specifically covered by the PURA in an integrated fashion to other river basins in Recife and neighboring cities.

Therefore, the concept of Capibaribe Park goes beyond a linear park zone of approximately $1 \mathrm{~km}$ in width along the whole river, from Várzea neighborhood to Recife's city center in order to encompass a whole park system and a park city.

Empirical features of the planning exercise include the various presentations, discussions, negotiations, and proposal agreements involved in the PURA Capibaribe Park Project interventions. The convergent process that these components combine to create incorporates various social and political segments of society: private citizens, social movements, professional organizations, universities and other educational institutions, stakeholders from the real estate and construction industries, and residents' associations, in addition to the local and state authorities.

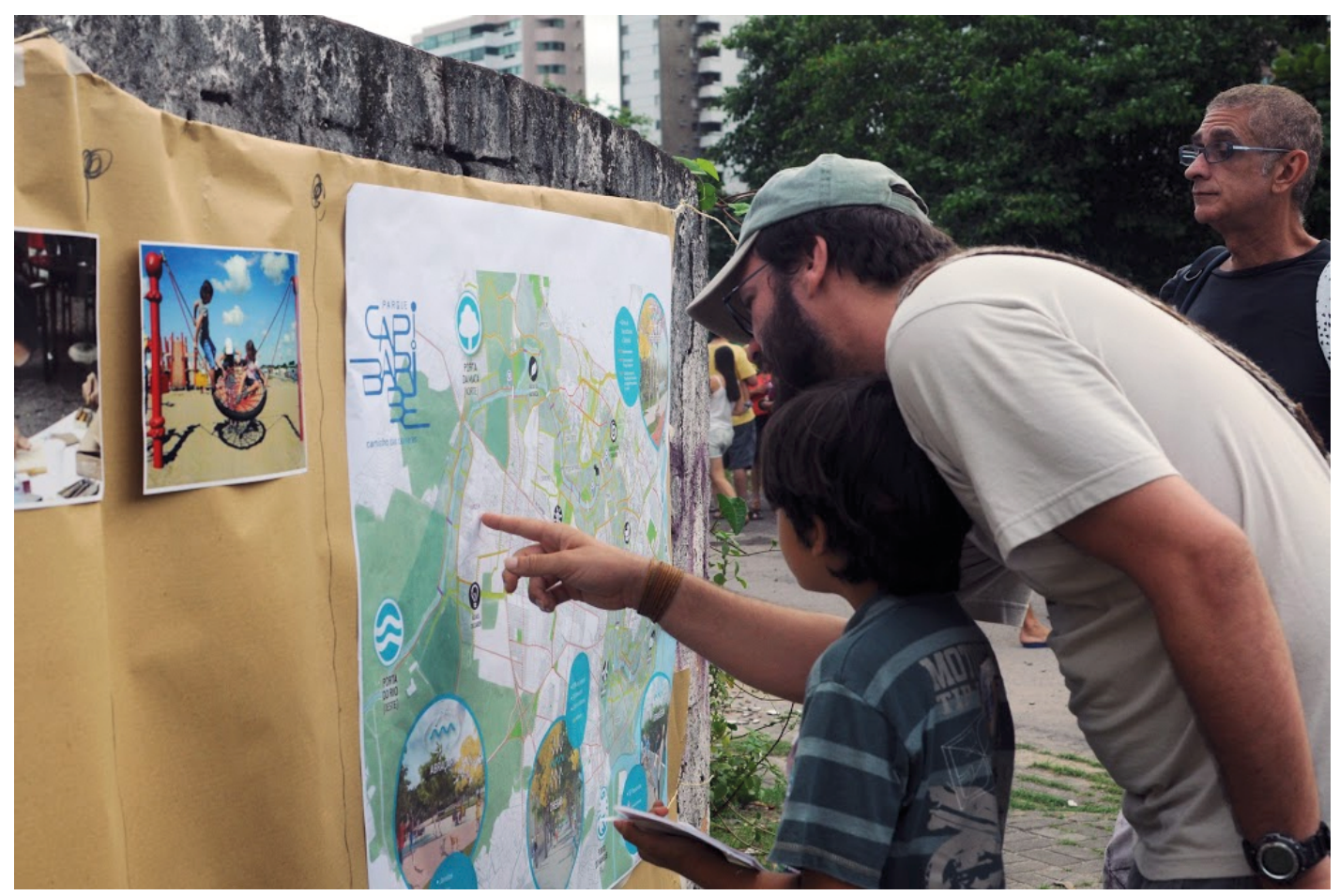

Source: INCITI-UFPE (2019).

Figure 8 - Convergence. 
Activities included workshops, regional and themed conferences, debates, and public consultations (Figure 8). The project also organized events to promote its innovative approach. These include so-called 'beaches' - temporary riverside installations used for social events, celebrations and entertainment - that attract large crowds and encourage large numbers of people to play a more active role in promoting the proposals under negotiation.

Examination of local circumstances revealed the potential to integrate various streams and canals, forest reserves and open spaces in urban settings (parks, squares, streets lined with trees), with the so-called 'seepage' into the park zone. This seepage, like the branches of the river itself and its banks, extends into the countryside, reaches neighborhoods and communities further afield and can be installed both along Capibaribe's tributaries and on roads that connect these with the river bank. The integration of various urban landscape systems, combining natural environment, infrastructure, and various complex social needs, is achieved by the creation of shared living spaces. These systems are connected to one another systems by passages that encourage passers-by to share the space. Shared spaces tend to attract greater circulation and promote spontaneous security surveillance.

In view of this potential, the park is structured around five key premises relating to regeneration, renovation and installation of thoroughfares and public spaces to encourage use. They are:

- arriving;

- embracing;

- crossing;

- following;

- activating.

Arriving at the river via parks should be a pleasant experience, encouraging people to walk more (Figure 9). This is related to the urban seepage that expands the sphere of influence of Capibaribe Park, even reaching the busiest city streets and bringing life and movement to the periphery, installing structures that promote movement near the riverbanks or further afield:

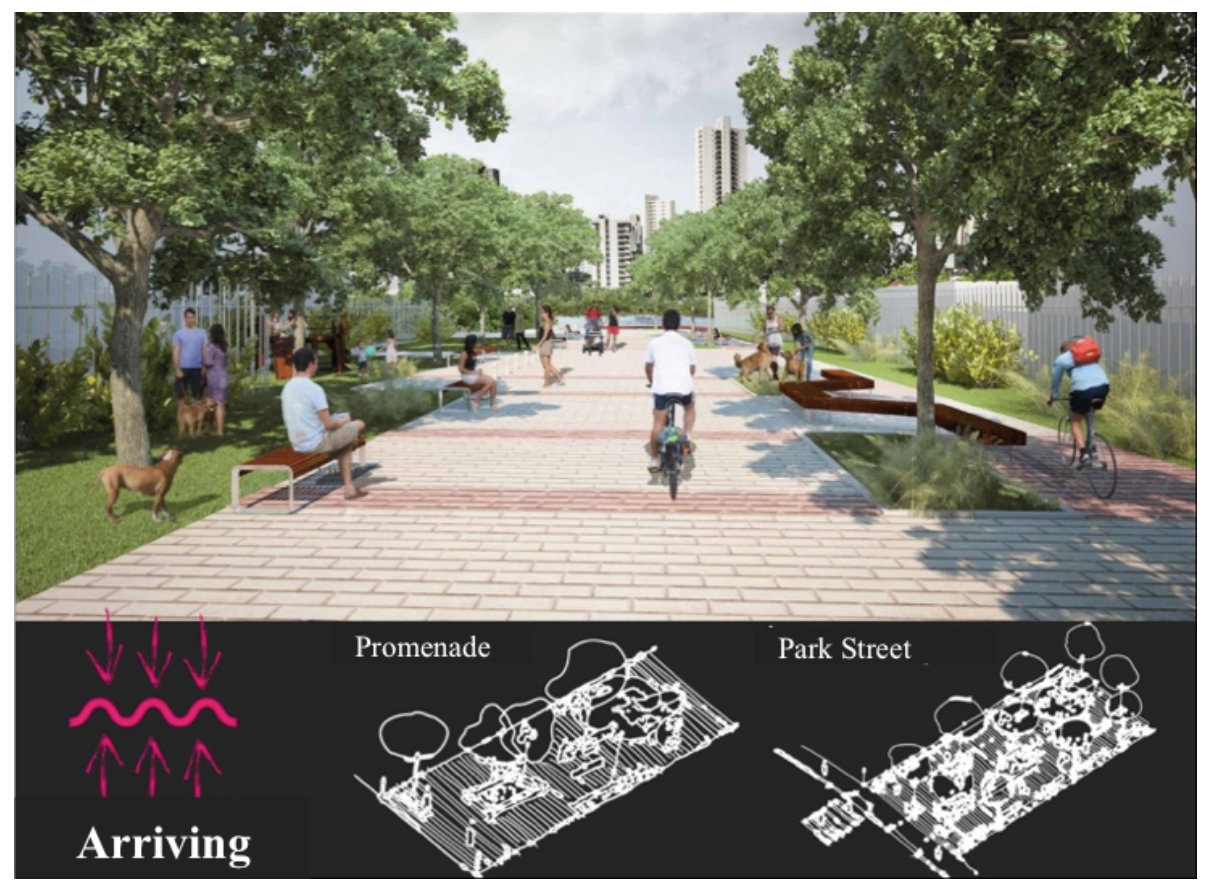

Source: INCITI-UFPE (2019).

Figure 9 - Arriving. 
- parks, squares, and markets;

- urban integration routes receiving an intense flow of non-motorized and motorized transportation;

- historical routes and routes with tourist potential.

Embracing (Figure 10) creates stopping points, providing leisure activities, and places for residents to meet and spend time together. This develops two concepts of space:

- 'beaches', which are broad linear spaces duly equipped to bolster the occupation and use of strategic points on the riverbanks as leisure areas;

- windows, with spaces in locations that are highly suitable for the contemplation of the river landscape.

Continuous vegetation cover on both banks structuring the ecological corridor of the river Capibaribe, paradoxically creates a visual barrier that blocks the water view. The challenge with window spaces is to find stratagems for reconciling two needs: the need to remove vegetation to enable residents to see the river; and, simultaneously, the need to preserve and establish the continuity of the ecological corridor.

Crossing (Figure 11) reduces the distance between locations on opposite sides of the city, improving the connectivity of the transport network. This can be achieved with sculpture-like bridges for pedestrians and cyclists, ferry crossings, or another solution that allows individuals to safely cross from one bank to the other. Considering that the river Capibaribe also acts as a barrier, connecting both river banks at strategic points, will have an effect not only at the local level, but also on the overall structure of the city. Furthermore, for over half of its course in the city, there are few bridges. Crossings would thus reduce the distance between locations within Recife City.

Following (Figure 12) entails the creation of a structural element that englobes the totality of the spaces that line the river banks and gives the park the feeling of a single body. It envisages solutions for moving up and down the river, along its banks, across walkways, but also by boat and by using the public river transport system. The stripped down, less complex transport axis

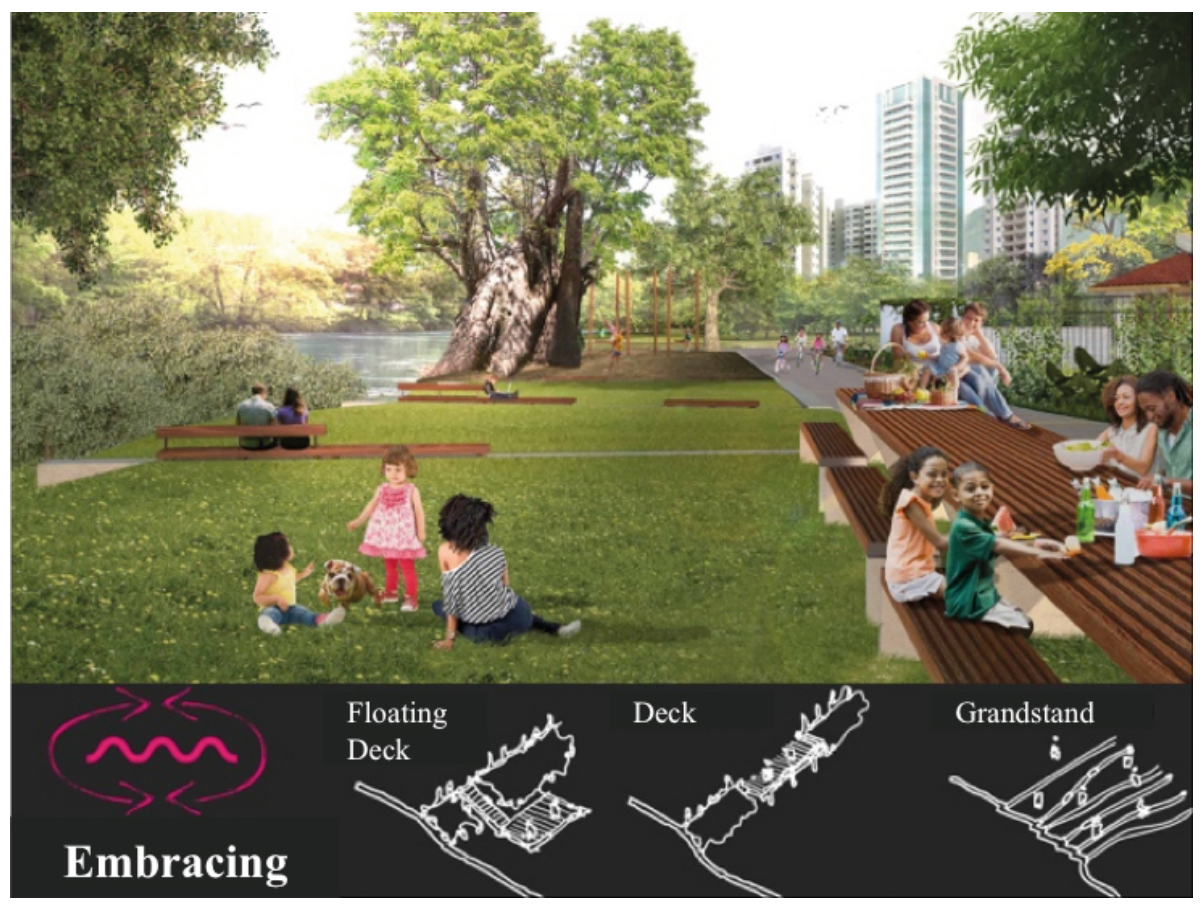

Source: INCITI-UFPE (2019).

Figure 10 - Embracing. 


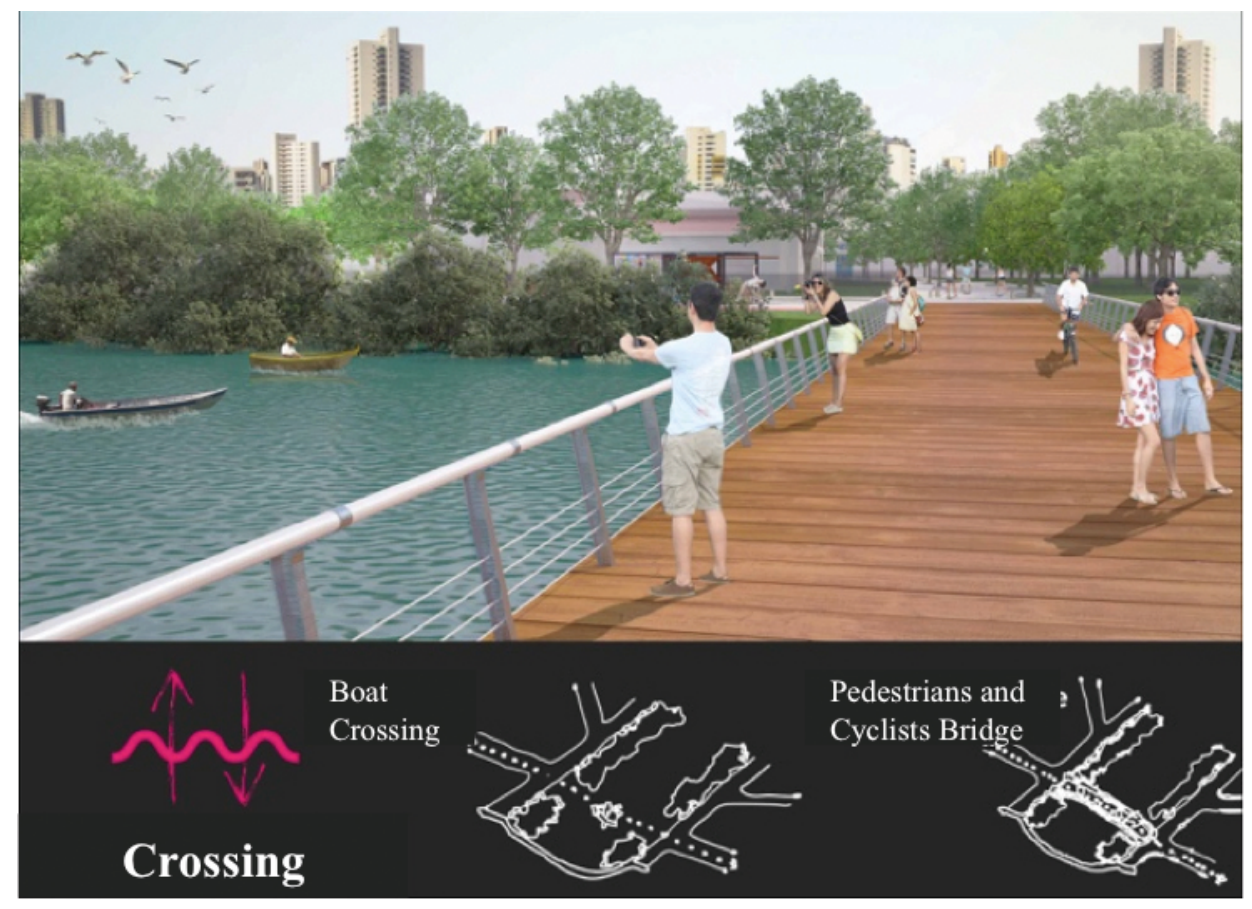

Source: INCITI-UFPE (2019)

Figure 11 - Crossing.

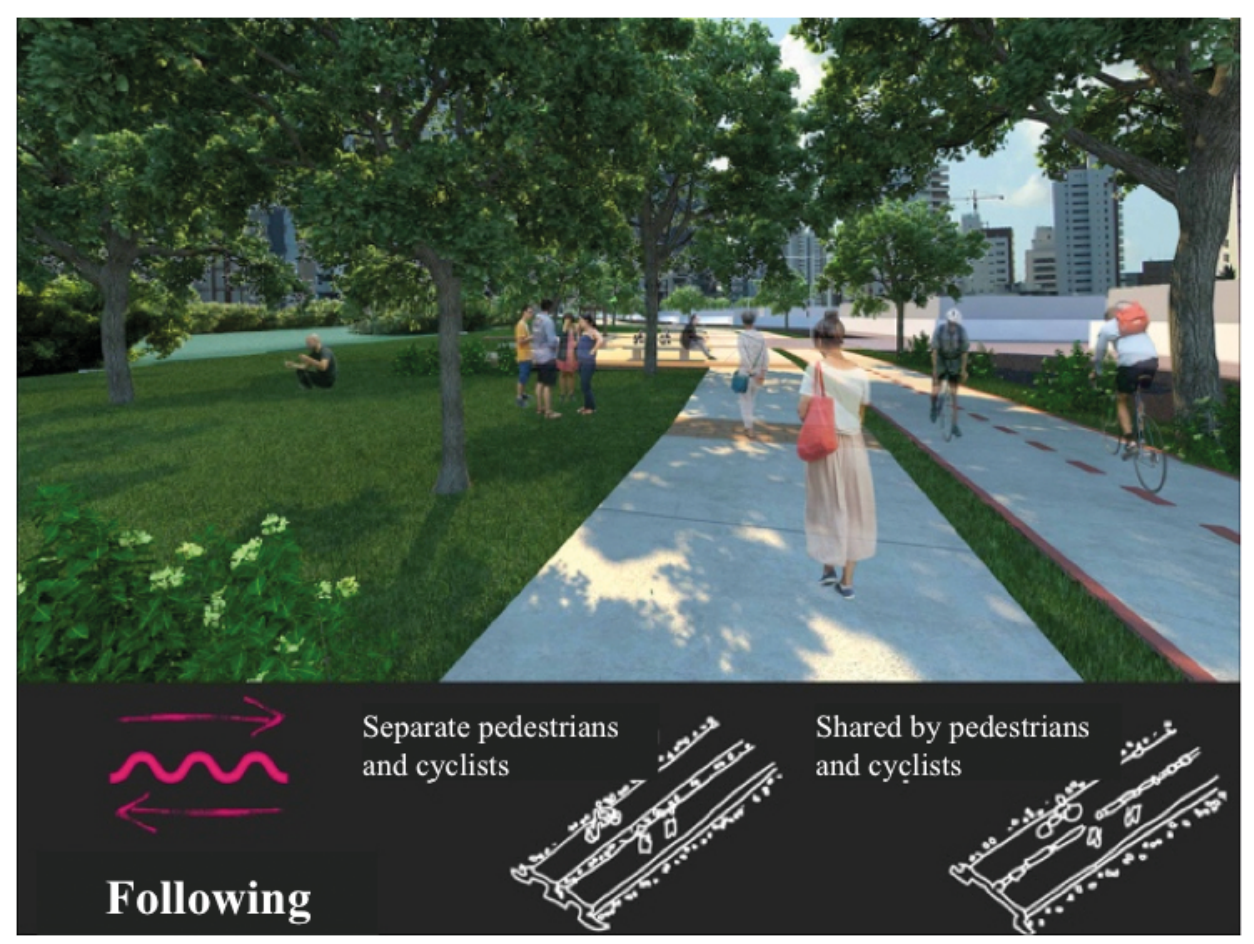

Source: INCITI-UFPE (2019).

Figure 12 - Following. 
communicates a desire to create points of tranquility, repose, and visual silence, guiding the eye towards a clearer view of the river landscape. The project thus pays homage to the landscape by providing recreational, educational and ecological walks, and reclaiming the banks of the river Capibaribe for the citizens of the city.

Finally, Activating (Figure 13) aims to bring vitality to urban spaces, arranging them in such a way that they are able to host cultural, social, sporting and business events at various points in Capibaribe Park, and encouraging its use and appropriation by the local population. It also aims to provide community and institutional management in partnership with the private sector, non-profit organizations, and private citizens. This approach may provide the conditions for full-functioning and use of efficient management for safe and well-maintained public spaces.

As a whole, the full array of public works proposed by the project would establish conditions, which, taken together, would provide the kind of connectivity envisaged by May (2006), reconciling access to the riverbanks with protection of riverine ecosystems.

\section{CONCEPTION AND RESULTS: BRINGING ENCHANTMENT, PATHS TOWARDS A PARK CITY}

The proposals developed in the course of the project are structured around a gradual implementation, aiming to achieve a transformation that is not only physical and spatial, but also cultural, in relation to the river and the waters of the city. Bringing public sector managers, lawmakers, social movements, businesses, and citizens into this culture will generate the synergy needed to ensure these proposals come to fruition. Capibaribe
Park Project is thus envisaged to be the first stage in this transformation. The wider repercussions of the proposals are being approved, in the form of pilot interventions. The long-term potential can already be seen from the results already achieved, to the point that the idea of a single park was insufficiently ambitious has become clear. It is now possible to envisage the broader prospect of creating an entire park city (Figure 14).

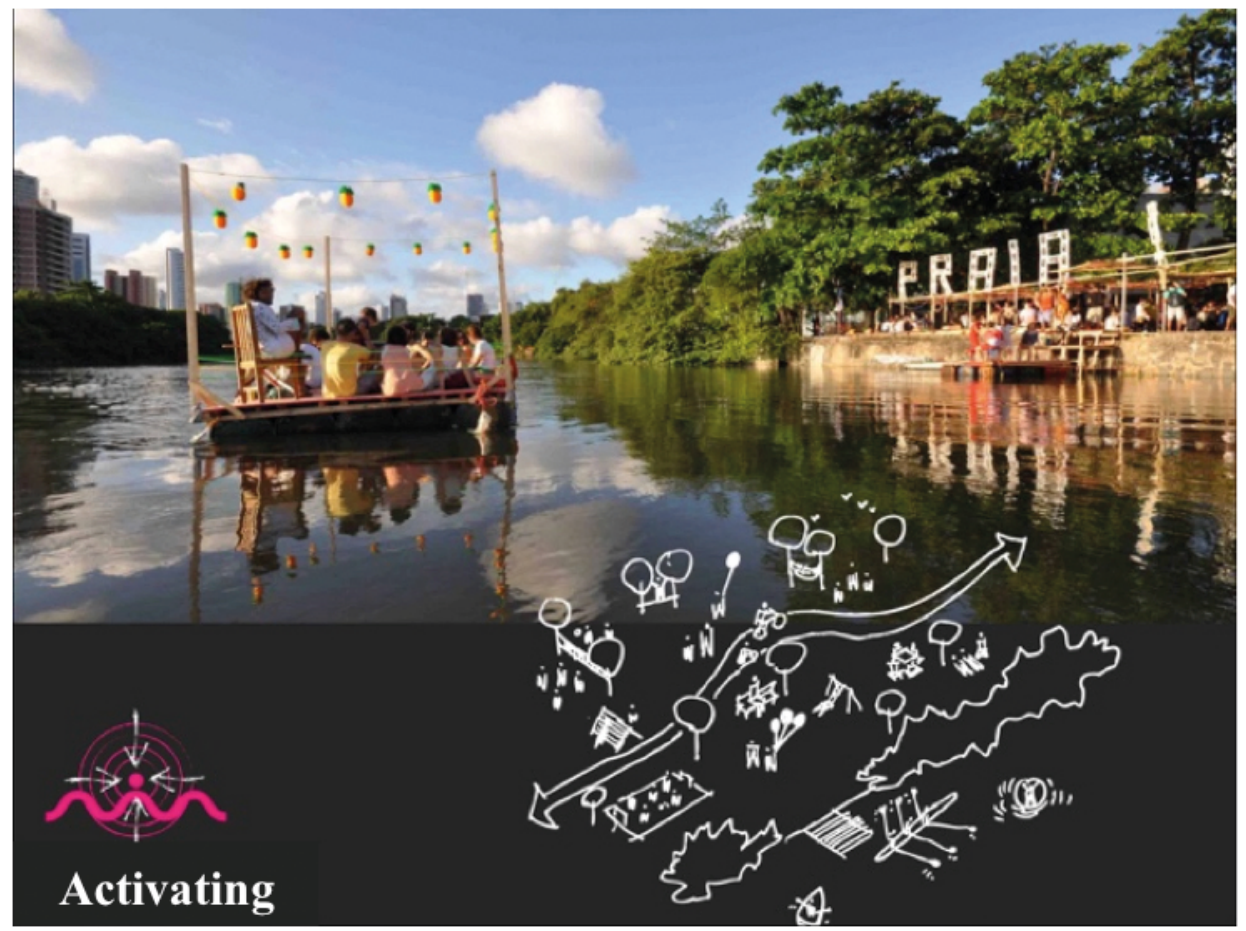

Source: INCITI-UFPE (2019)

Figure 13 - Activating. 

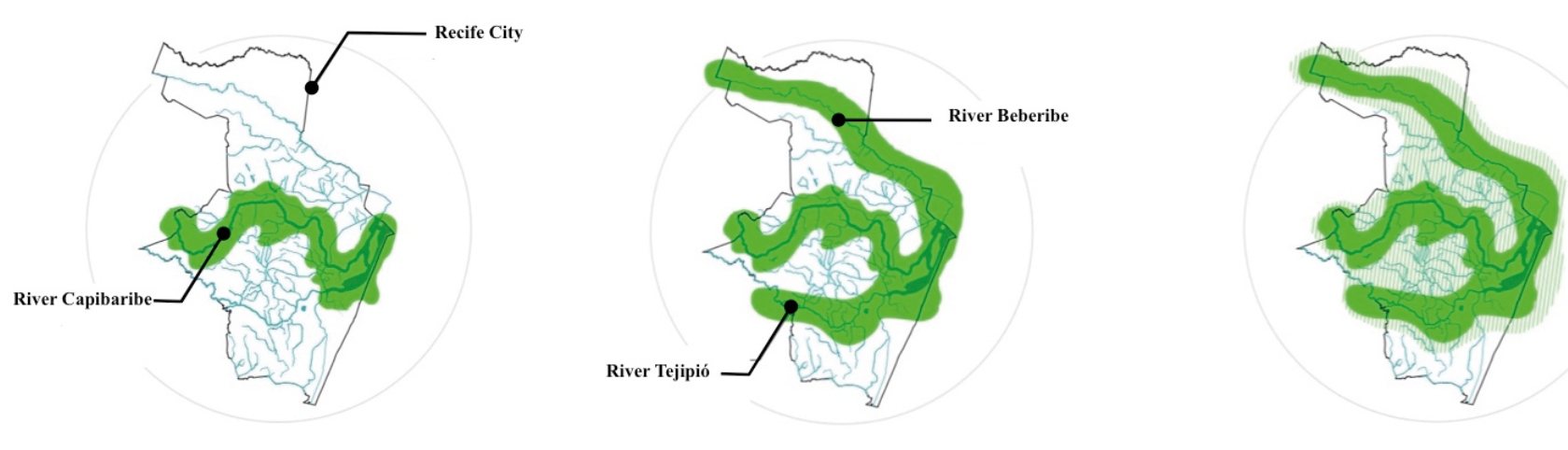

………

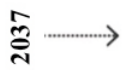

Source: adapted from INCITI-UFPE (2019).

Figure 14 - Capibaribe Park (Park Zone), System of Parks, Park City.

In the long term, this project faces the greater challenge of appropriation of the urban plan and demands (or pressure) by the population to implement it as discussed and agreed collectively. This also needs to be achieved in a situation in which there is as solution to the issue of continuity across local government administrations, with continuous monitoring and evaluation by academics and an organized civil society. Such continuity is the only way to avoid the project ending up, like many other grand plans for the cities, which are shelved and eventually forgotten, never to see the light of day.

In view of public and private investment restrictions and priorities, implementation needs to be achieved by citizens, making this dream of changing the city something of their own. For these people to have a dream of the future, they need to fall in love with the project now and fight for the park to be made a reality tomorrow.

The need to reach this enchantment stage has resulted in the development of a pilot project along $4 \mathrm{~km}$ of the river's left bank, between Parque de Santana Park and Praça do Derby, connecting public spaces that have been regenerated or whose regeneration is under proposal. The area was chosen for various reasons:

- its location on a stretch half way along the course of the river, providing the opportunity for expansion up- or downstream;

- the impossibility of moving around on foot or by bike because of the occupation of the riverbanks by roads and apartment blocks;
- a desire to meet the needs of a variety of economic and social strata of the population in the $500 \mathrm{~m}$ sphere of influence of the intervention;

- the visibility of the area, serving as an example for the city residents;

- the presence of a rich historical heritage in the vicinity;

- the existence of two parks and four squares within the area covered.

The project attempted to reveal the landscape of the river so that people could take possession of this heritage by way of one-off interventions that provide places to relax and make it easier to move around. As in the RxA workshop, which sparked debate on the possibility of using the river Capibaribe to transform the city, the project adopted an approach similar to that of the green and blue zones in France. Fascination of water is represented by blue spaces, which are characterized by the presence or influence of or direct contact with water. Vegetation is represented by green spaces, which include the riverside's fauna and flora. And the coexisting surrounding buildings constitute the gray space, which is artificial and made by humans. Together, these three spaces can spark a revival of riverside life.

Sustainability is one of the key premises of the urban planning project, and the proposed solutions thus emphasize:

- the use of highly durable local materials; 
- a low energy consumption public streetlighting system, with minimal impact on the local fauna;

- a predominance of native species of plants, which require low maintenance and irrigation;

- promotion of commerce and informal services, such as infrastructure and auxiliary equipment;

- the creation of co-operatives to collect and recycle solid waste, produce compost, set up community vegetable gardens and teach gardening skills;

- prioritization of non-motorized transport.

Pedestrian walkways and cycle routes that line the river should help interconnecting public spaces and facilitate circulation. Places to rest and relax, such as benches, will be provided at intervals of $200 \mathrm{~m}$. These will be of specific benefit to the elderly and people with disabilities. All walkways and public spaces will follow the norms of the overall design. Where there is room,
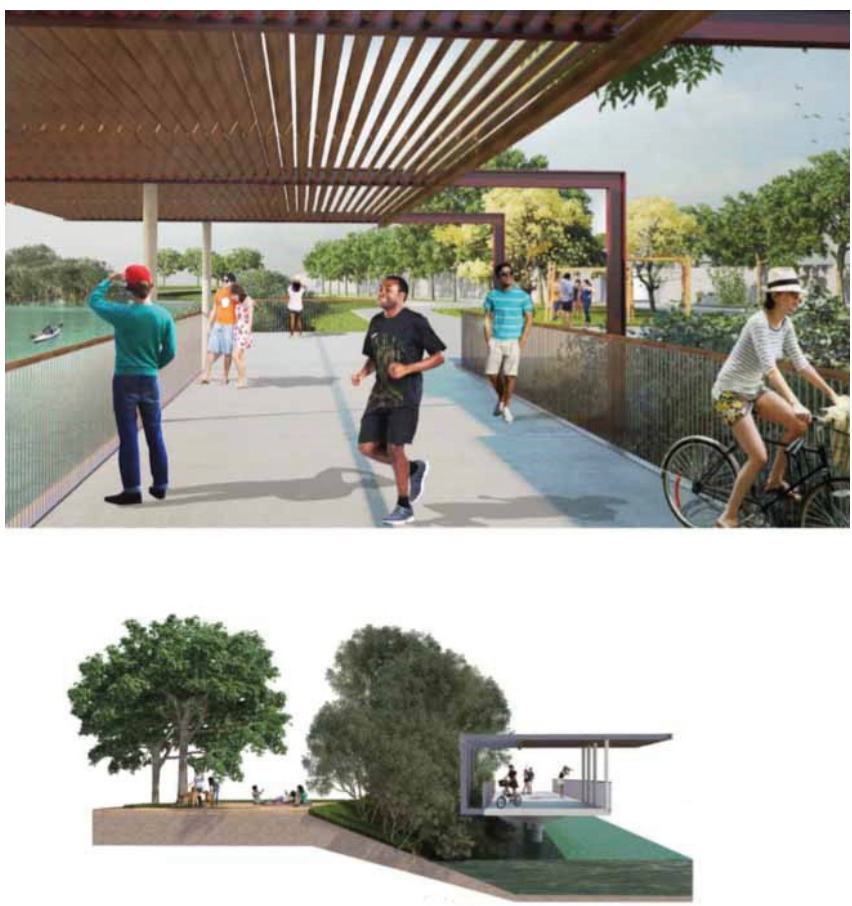

Source: INCITI-UFPE (2019).

Figure 15 - Riverside Walkway

Proposals for Graças: proposal 1. walkways will be provided across the river and along its banks, mounted on pile-driven posts in the river, with low-environmental-impact prefabricated honeycombed slabs. Walkways symbolize the project as a whole, giving people the opportunity to walk over the river, to view the various landscapes produced by this enormous body of water, and to observe the riverside fauna and flora (Figures 15 and 16).

The principle of regeneration of existing public spaces is also applied to Antônio Maria and Vintém Squares, where the proposal is to eliminate the streets that separate them from the river, resulting in direct contact with the riverbank and transforming them into parks. This serves to gradually augment the already existing linear space along the river and help recover irregularly occupied riverbanks. Each square will be treated differently. Antônio Maria Square, next to a school, will be endowed with leisure facilities and a children's playground, enabling children once again to play spontaneously outdoors, and helping to make Recife a child-friendly city. In Vintém Square, near a local urban hub (with local shops, a supermarket, and a mall) and a
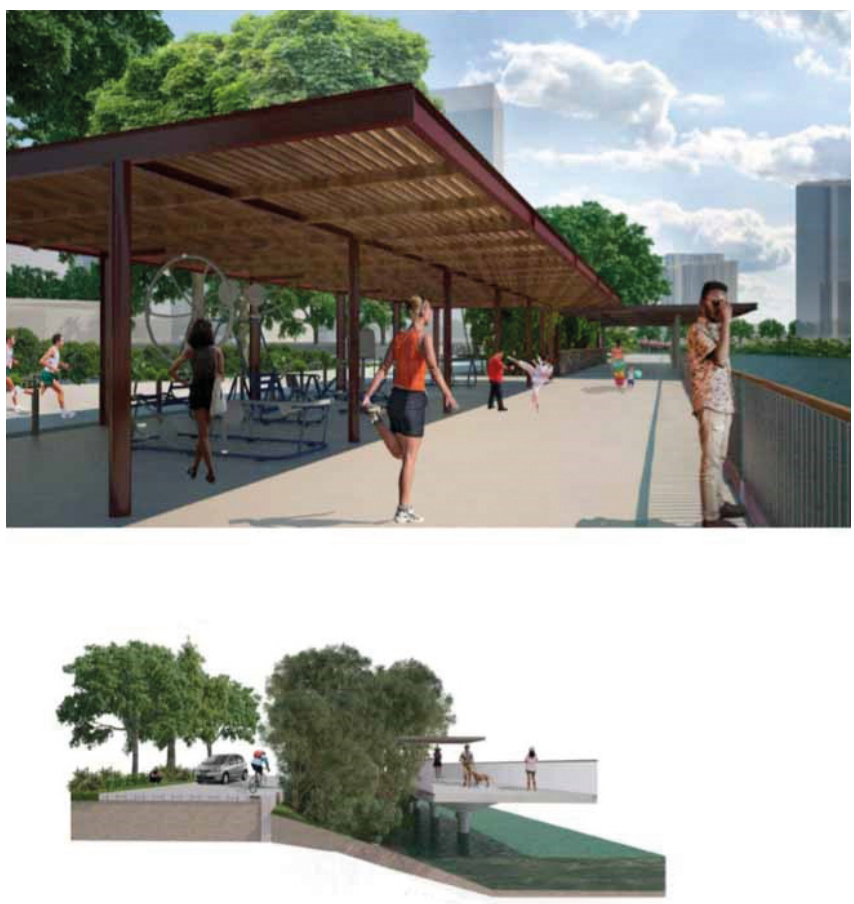

Source: INCITI-UFPE (2019).

Figure 16 - Riverside Walkway

Proposals for Graças: proposal 2. 
low-income community, public spaces will be equipped with food stalls for the street vendors who already work in the area, with beauty spots, and a refuge for riverside fauna.

In Jaqueira Park, alongside one of the most stunning city's riverscapes, where Capibaribe makes an almost 180 o turn, there is a plan for an amphitheater that exploits the natural topography of the river bank. This would provide direct contact with the river with a floating pier, beauty spots and various meeting points shaded by trees.

In the immediate vicinity of an old riverside streetcar stop named Ponte D'Uchoa there is an extraordinarily beautiful 200-year-old baobab tree, which was until recently walled off by irregular riverside properties. Recife City Hall recovered an $18 \mathrm{~m}$ wide stretch on the edge of a lot and used it for Baobab Garden Project, the first pilot intervention of Capibaribe Park Project. This stage is already complete, and the garden is be- ing used, managed and maintained as agreed by local residents and businesses, with the support of the park activation team (Figure 17).

Baobab Garden realized the potential foreseen by the project and became a tourist attraction. The small floating wharf encourages people to cross the river in ferries at the few points in which this is possible. There is now a considerable number of ferries, underlining the importance of providing urban mobility solutions, using this overlooked form of river transport. This fact inspired the innovative Navegue app, developed by a local startup incubated by Porto Digital, Recife, which aims to provide solutions for expanding river transport by regulating the operation of ferries using water navigation technology.

The project's pilot interventions include the $\mathrm{INCl}$ TI-UFPE team's response to a request from residents of the neighborhood Graças, which organized a movement called Graças for Us, in reaction to a City

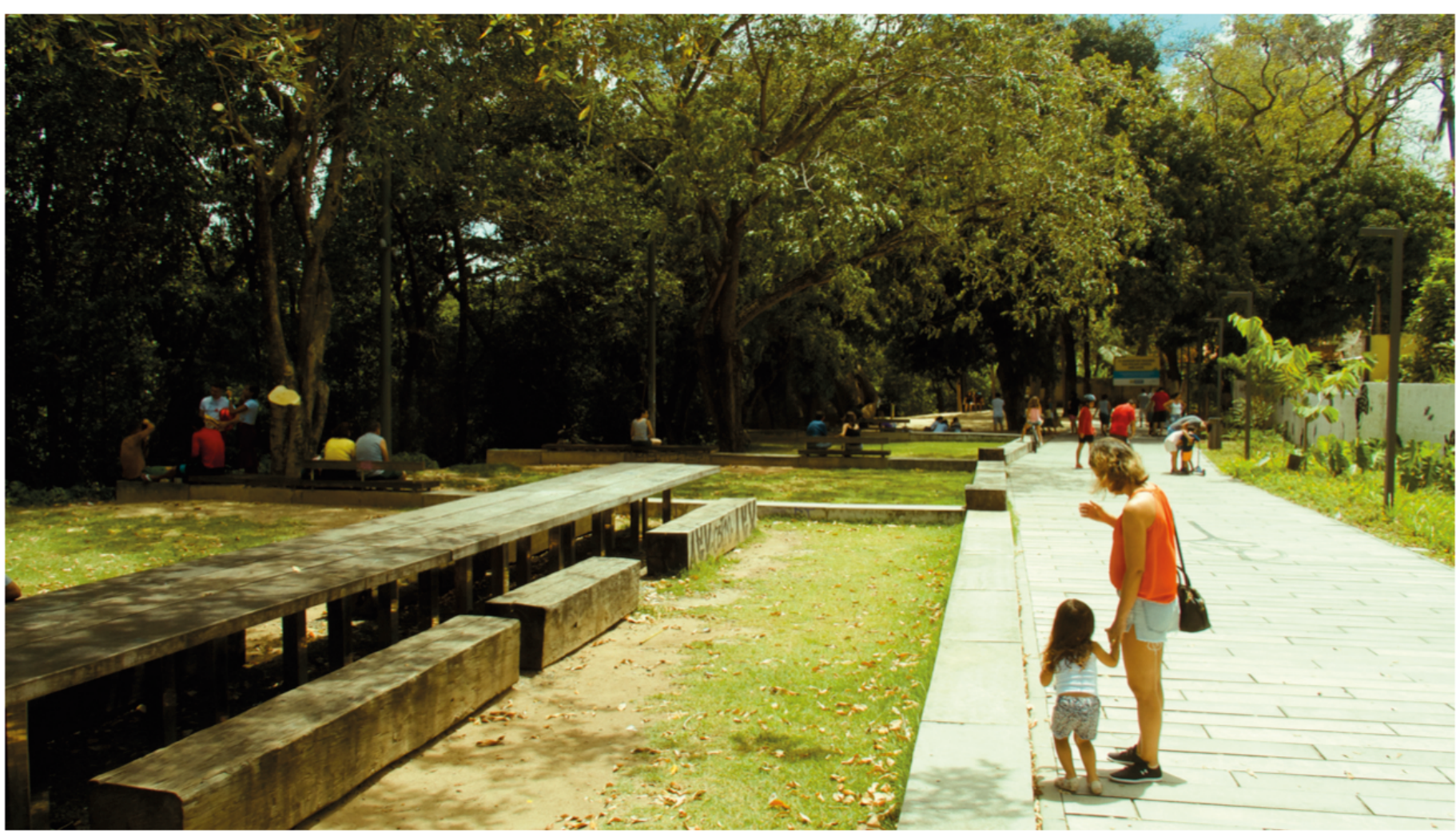

Source: INCITI-UFPE (2019).

Figure 17 - Baobab Garden, pilot Capibaribe Park Project intervention. 
Hall project that used already available resources to install a four-lane expressway along the river banks between Torre and Capunga Bridges. Aware of the park concept, the movement argued for the implementation of these principles and became part of a park project collaboration with Recife City Hall with the INCITI activation team. The result was the development of a park way, with walkways, squares, a single-lane main road for cars and bicycles, under the shade of native species of trees. Although it has

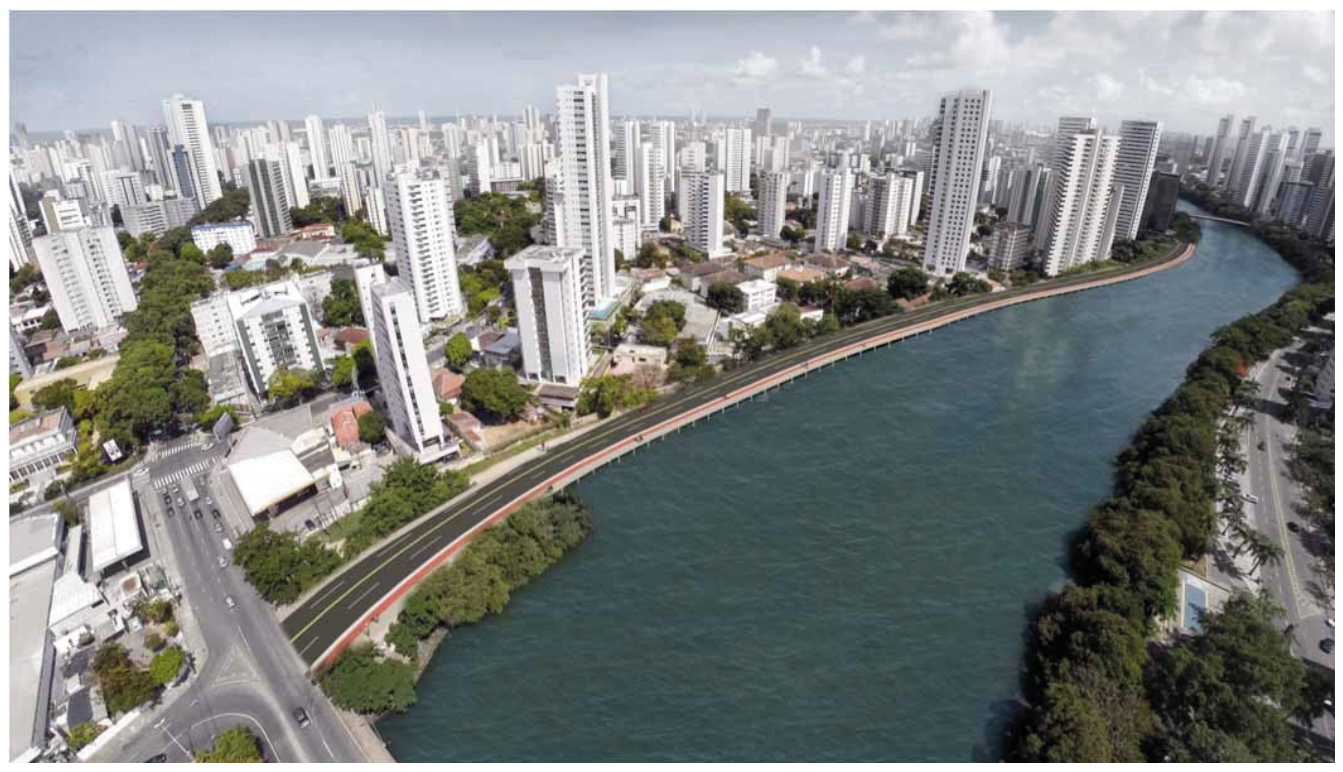

Source: INCITI-UFPE (2019).

Figure 18 - Four-lane riverside expressway project.

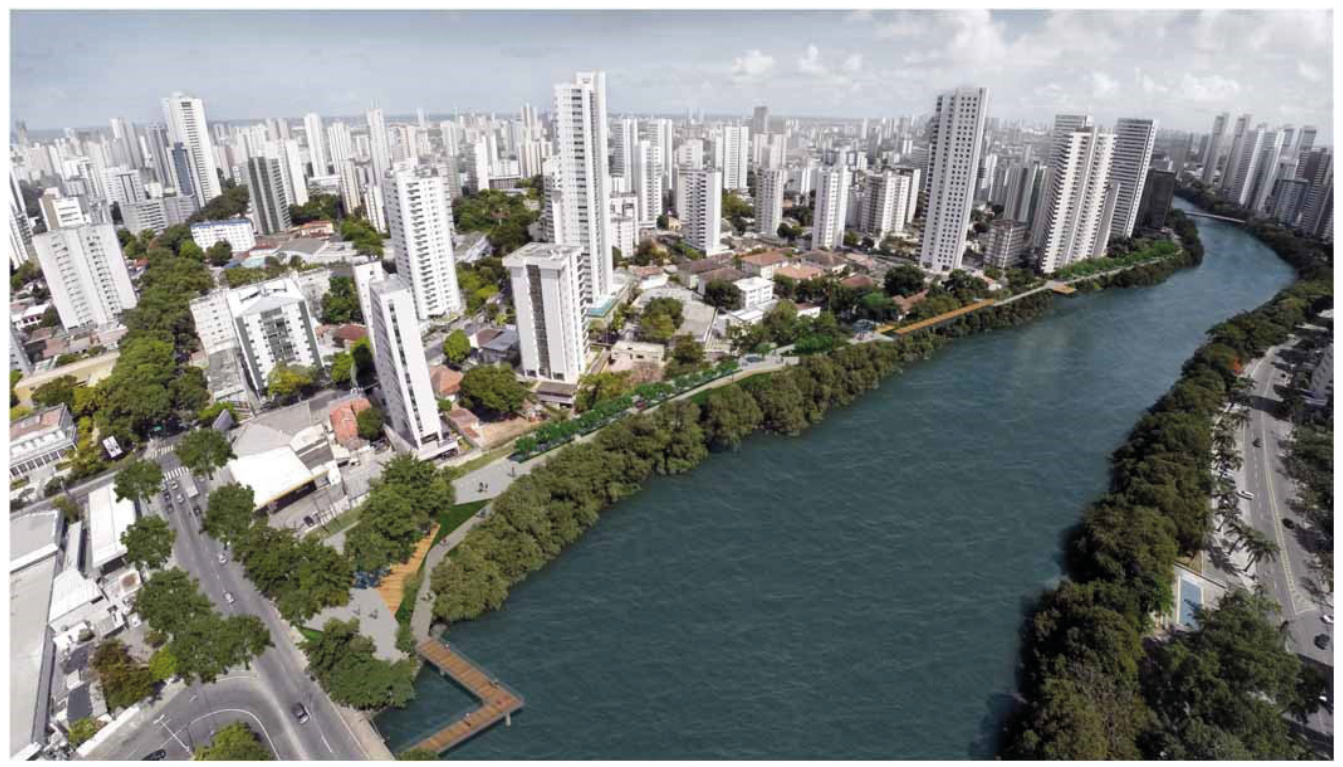

Source: INCITI-UFPE (2019).

Figure 19 - Walkway project along the left bank of the river Capibaribe. 
altered the focus of mobility from cars to cyclists and pedestrians, Caixa Econômica Federal bank agreed to continue with it. In comparison with the original project, centered on the automobile (Figure 18), with the project now implemented, which preserves river banks and values, as a location for riverside walks (Figure 19), it shows the impact an approach that respects the urban environment can have on the quality of riverside spaces.

Likewise, in a project segment between Capunga and Derby Bridges, the expressway was replaced by public spaces with sidewalks and cycle routes, meeting the needs of students, professors and staff of a nearby university, as well as those of local residents. The activation team again supported the reconciliation of activities of street vendors (of food and drink) and other urban needs. The task was to meet a complex demand and develop a multi-purpose location appropriate for these individuals: a town square, a food area (with stalls and food trucks), sidewalks and cycle routes, relaxation areas, large open spaces for recreation, events and exhibitions. All this was funded by resources earmarked for mitigating the impact of the university's installation.

The enchantment phase will eventually be consolidated with the installation of three bridges for cyclists and pedestrians. These architectural interventions should result in the creation of sculpture-like structures within the river Capibaribe landscape and will be contracted in an international competition, thereby fulfilling all the premises of the pilot project: arriving, embracing, crossing, following, and activating.

\section{CONCLUSIONS}

The experience of developing Capibaribe Park Project from conception to installation of the first interventions and continuation of the strategic actions envisaged, provides material for evaluation and enriches the debate concerning the paradigms that should guide urban planning policies in general, and land use and water management in particular. The practical results of applying some concepts and premises have already given rise to much valuable reflections.

A digital model of the park zone (Figure 20) envisages regeneration of $51 \mathrm{~km}$ of roadways as park roads, the

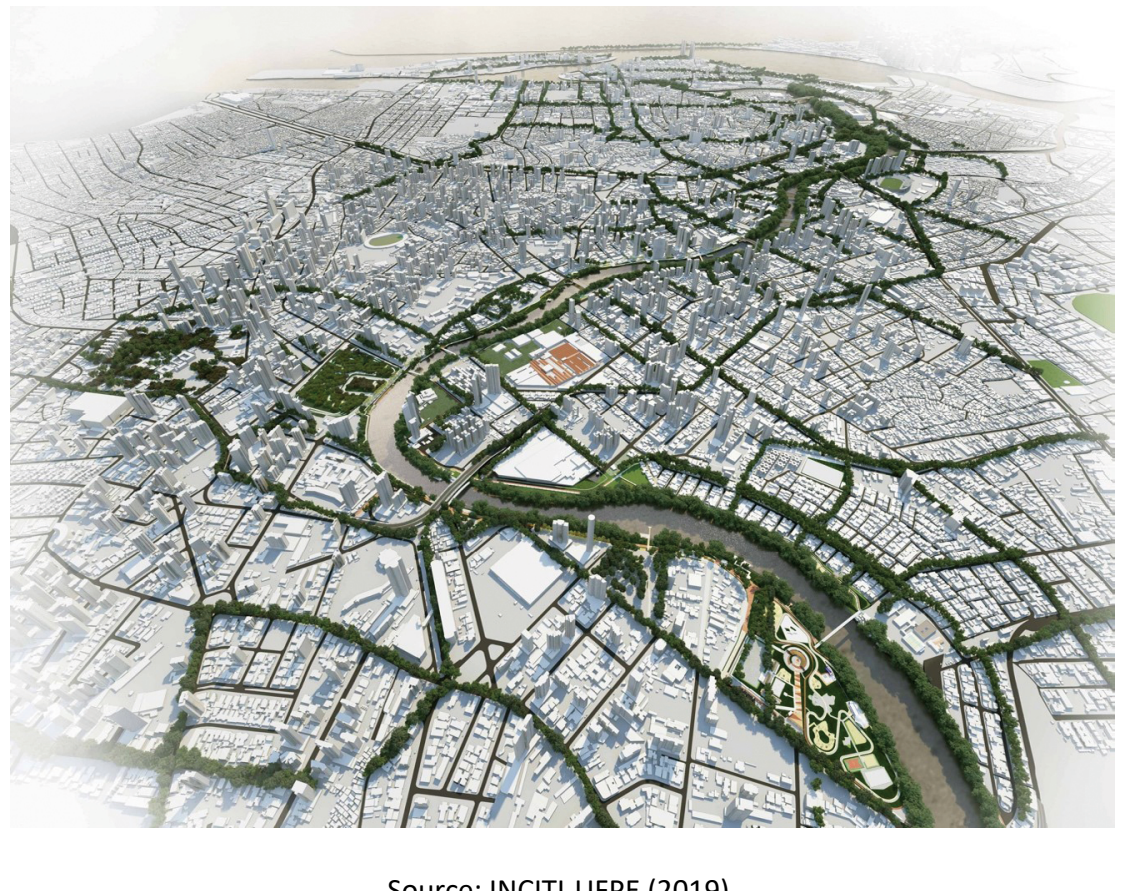

Source: INCITI-UFPE (2019).

Figure 20 - Conception of the Park Zone (digital model). 
installation of $45 \mathrm{~km}$ of cycle routes and an increase in the amount of public green areas in the city from $1.2 \mathrm{~m}^{2}$ per inhabitant (in 2014) to $20 \mathrm{~m}^{2}$ per inhabitant (in 2037), transforming Recife into a park city in time for its $500^{\text {th }}$ anniversary. The underlying structural principles are closely interconnected: sustainability and regeneration of public spaces are axes that bring about the ideal of equilibrium in the quality of human urban habitat, based on reconciliation of the city and its natural environment. This perspective covers issues such as the forecasting and prevention of risks related to urban resilience, although this is still not the focus of the project. The way forward thus involves teaching a new culture of land-use planning, promoted in everyday life in Recife, concerned with maintaining and valuing the capacity that water has to create pleasing orderly urban spaces and to confer greater cohesion in the city.

Given that Recife is an amphibious city, one challenge posed is that of countering the increasingly continuous and intense effects of rains, by focusing on urban structures and landscapes that move away from the prevailing culture of artificialization and domination of water. This involves investigating new paradigms such as:

- integration of sectors and disciplines;

- water-sensitive design;

- participation as activation (society becoming enchanted by the project and seeing it as its own).

In terms of the first element, the project broadly mobilized disciplines related to the issues at stake, and advanced proposals and solutions that bring together municipal public policy sectors, such as urban planning, environment, mobility, and economy. In terms of water-sensitive design, the project focuses partly on the concept of Water Sensitive Urban Design defined by Australia's National Water Initiative as "the integration of urban planning with management, protection and conservation of the urban water cycle that ensures urban water management is sensitive to natural hydrological and ecological processes" (COAG, 2004, p. 30).

In terms of public participation, the project is in line with the principles of educating society to coexist with urban waters, at various scales of intervention street, neighborhood, river basin, city - as suggested by authors such as Bernard Chocat (2003). It also prioritizes actions of a non-structural nature - participatory plans, management processes and monitoring - as guides for structural action involving physical infrastructure. This shifts a culture of control and opposition of city and nature, river, and citizen, posing the greatest challenge of all.

In city spaces, where the actions of residents and professionals such as hydrologists, architects and urbanists, landscapers, geographers, and sociologists overlap, some of the changes are covered by urban planning. In principle, this should lead to the promotion of equity in the built environment. This should involve not merely the replication of models, but responses suited to the reality and specific social spatial and physical environmental context of each city. Urbanism is a discipline capable of guiding the organization and control of the development of the city in relation to water. Professionals in this field are thus obliged to promote change by exercising skills such as creativity and innovation with approaches, analyses and solutions guided by the interrelations between social spatial and hydrological dynamics in the urban environment, receptivity, and facilitation of the participation of various other players. In this way, they hope to build hospitable and resilient cities.

Although initially limited to the scope of a collaboration with more restricted objectives, Capibaribe Park Project shows it can incorporate these other features and abilities, broadening both its physical spatial scope and its content. This experience consolidated approaches in which non-structural actions take on greater relative importance and guide those of a structural nature, including planning, participatory management, and collective oversight of convergence with activation, as shown by the outputs in Figure 7. More recently, INCITI has helped the Pelópidas da Silveira City Institute (ICPS) to review Recife's Master Plan, with a proposal for a Landscape Conservation Unit on the banks of the river Capibaribe. Researchers and professionals of UFPE are regularly invited to respond to demands not directly associated to the partnership discussed here. Hence, they have seen an increased recognition of their skills and knowledge and have presented practical solutions that combine urban planning and landscaping to use the river Capibaribe to reinvent Recife City. 


\section{REFERENCES}

BOURDEAU-LEPAGE, L. (ed.). Nature et ville: désirs et controverses. Bruguières: Éditions la Librairie des Territoires, 2016. $160 \mathrm{p}$.

BRODACH, A.; GOFFI, M. La politique de la ville: une trajectoire de développement urbain durable? Développement durable et territoire, Évora, n. 4, p. 1-15, 2005. Available from: <http://developpementdurable.revues.org/ document1493.html>. Accessed on: Feb. 14, 2008. https://doi.org/10.4000/developpementdurable.1493

BRUN, A. Introduction: les objectifs, principes et éléments de débat. In: BRUN, A.; LASSERRE, F. (eds.). Les politiques de l'eau: grands principes et réalités locales. Québec: Presses de l'Université du Québec, 2006. p. 1-14.

BRUN, A.; COURSIÈRE, S.; CASETOU, É. Eau et urbanisme à Lyon: le projet de renaturation du Ruisseau des Planches. Territoire en mouvement, v. 22, p. 112-126, 2014. Available from: <http://journals.openedition.org/tem/2475>. Accessed on: May 3, 2019.

CARNEIRO LEÃO, T. (ed.). Livro Geral Poemas Carlos Pena Filho. Recife: published by Editor, 1999. 159 p.

CASTRO, J. de. A cidade do Recife: ensaio de geografia urbana. São Paulo: Gráfica Carioca, 1954. 167 p.

CASTRO, J. de. Homens e caranguejos. São Paulo: Brasiliense, 1967. 188 p.

CHOCAT, B. Pour intégrer les eaux pluviales. Rapport international sur la gestion des eaux pluviales urbaines. In: CONSEIL GÉNÉRAL DE SEINE-SAINT-DENIS (ed.). Apprivoiser l'eau pluviale, une démarche de projet urbain pour une ville durable. Bobigny: Département du Travail, 2003. p. 28-34.

COUNCIL OF AUSTRALIAN GOVERNMENTS (COAG). Intergovernmental agreement on a national water initiative. Camberra: Council of Australian Governments, 2004. Available from: <https://www.pc.gov.au/inquiries/completed/ water-reform/national-water-initiative-agreement-2004.pdf>. Accessed on: Oct. 4, 2018.

DINIZ, F. R. "Eau-urbanisation", une utopie à la brésilienne: drainage et aménagement dans la Région Métropolitaine de Recife. Thesis (Doctoring in Geography) - IHEAL, Université Paris III, Paris, 2010.

DOLLFUS, O. El espacio geográfico. Barcelona: Oikos-Tau Ediciones, 1990. 128 p.

FORMAN, R. Ecologia urbana e distribuição da natureza nas regiões urbanas. In: MOSTAFAVI, M.; DORHERTY, G.; CALISTO, A. M. D.; VALENZUELA, L. (eds.). Urbanismo Ecológico. São Paulo: Gustavo Gilli, 2014. 306 p.

INSTITUTO BRASILEIRO DE GEOGRAFIA E ESTATÍSTICA (IBGE). Censo de 2010. IBGE, 2010. Available from: <http://www. ibge.gov.br/home/estatistica/populacao/censo2010/default.shtm>. Acessed on: Sept. 19, 2018.

INTERgOVERNMENTAL PANEL ON CLIMATE CHANGE (IPCC). Climate Change 2013: The Physical Science Basis. Contribution of Working Group I to the Fifth Assessment Report of the Intergovernmental Panel on Climate Change. Cambridge: Cambridge University Press, 2013. 1535 p.

LIMA, S. M.; GARCEZ, D. S. Áreas verdes públicas urbanas e sua relação com a melhoria da qualidade de vida: um estudo de caso em um parque ecológico urbano na cidade de Fortaleza (Ceará, Brasil). Revista Brasileira de Ciências Ambientais, Rio de Janeiro, n. 43, p. 140-151, 2017. Available from: <http://rbciamb.com.br/index.php/Publicacoes_ RBCIAMB/article/view/123>. Accessed on: Mar. 4, 2020.

MAY, R. "Connectivity" in urban rivers: Conflict and convergence between ecology and design. Technology in Society, v. 28, n. 4, p. 477-488, 2006. https://doi.org/10.1016/j.techsoc.2006.09.004

MELO NETO, J. C de. Obra completa. Rio de Janeiro: Nova Aguilar, 1999. 836 p. 
OLIVEIRA, W. de. Geologia da Planície do Recife: contribuição ao seu estudo. 97f. Thesis (Concurso à cátedra de História Natural) - Escola Normal Oficial de Pernambuco, Recife, 1942.

PESQUISA E INOVAÇÃO PARA AS CIDADES-UNIVERSIDADE FEDERAL DE PERNAMBUCO (INCITI-UFPE). PURA: Plano de urbanização e resgate ambiental da bacia do rio Capibaribe. Recife: PCR / INCITI-UFPE, 2019.

PINCETL, S. La durabilité urbaine et la nature en ville: le besoin d'interdisciplinarité. In: MATHIEU, N.; GUERMOND, Y. (eds.). La ville durable, du politique au scientifique. Paris: Cemagref, Cirad, Ifremer, INRA, 2005. p. 209-220.

PREFEITURA DA CIDADE DO RECIFE. Atlas das infraestruturas públicas em Comunidades de Interesse Social do Recife. Recife: Autarquia de Saneamento do Recife, 2016. 165 p.

PROGRAMA DAS NAÇÕES UNIDAS PARA O DESENVOLVIMENTO (PNUD); INSTITUTO DE PESQUISAS ECONÔMICAS APLICADAS (IPEA); FUNDAÇÃO JOÃO PINHEIRO (FJP). Atlas do Desenvolvimento Humano nas Regiões Metropolitanas Brasileiras. RM do Recife. Brasília: Instituto de Pesquisas Econômicas Aplicadas, 2014. Available from: <https://www. ipea.gov.br/portal/index.php?option=com_content\&id=24037>. Accessed on: May 8, 2018.

ROBERTS, D.; GORE, C.; BULKELEY, H. (eds.). Climate change in cities: innovations in multi-level governance. The urban book series. Nova York: Springer, 2018. 378 p. 